\title{
Принцип построения корпуса нормативно-технических документов
}

\section{Дополнительный материал к научной статье на тему оценки прикладного качества тематических моделей для задач кластеризации}

\section{Ф. В. Краснов, Е. Н. Баскакова, И. С. Смазневич}

Ключевые слова: анализ текста; текстовый корпус; тематическое моделирование; мягкая кластеризация; когерентность темы.

Научная работа в области анализа текста требует обеспечения подходящего набора экспериментальных данных в соответствии с решаемой задачей.

В частности, среди критериев отбора подходящих текстов можно отметить следующие:

- Общее число документов в корпусе;

- Среднее количество термов в документе и однородность длин документов корпуса;

- Объем словаря корпуса и распределение частот термов;

- Тематическое содержание корпуса: тематика корпуса документов, распределение тем среди документов корпуса, степень тематической однородности каждого из документов корпуса;

- Структурированность каждого документа, однородность структуры документов корпуса;

- Языковая принадлежность документа и число использованных в корпусе языков;

- Стиль текста каждого из документов, стилевая однородность корпуса документов;

- Присутствие именованных сущностей в текстах, число типов сущностей в корпусе, специфичность сущностей.

Выбор корпуса для использования в экспериментах по анализу текста основывается на человеческой оценке документов корпуса по указанным критериям. Например, опубликованные корпуса большого объема [1] не всегда могут подойти в качестве экспериментальной базы для исследований по интеллектуальному анализу текста в силу большой сложности расчетов при ограниченных вычислительных pecypcax.

В задачах, связанных с кластеризацией и тематическим анализом коллекции текстовых документов, требуются документы средней длины, структурированные и тематически однородные, с единым стилем изложения при достаточном объеме словаря.

В статье «Оценка прикладного качества тематических моделей для задач кластеризации» авторов Ф. В. Краснова, Е. Н. Баскаковой, И. С. Смазневич исследуются методы оценки качества тематических моделей, способные обеспечить их устойчивое применение для решения практических задач, связанных с анализом набора текстовых документов. В работе на примере задачи мягкой кластеризации показано, что использования метрики средней когерентности тем недостаточно для оценки применимости построенной модели и целесообразно учитывать показатели связей документов с высококогерентными темами.

Для экспериментального исследования при решении указанной задачи использовались два набора русскоязычных документов:

- «Тайга»: 7695 текстов средней длины (среднее количество термов в одном документе - 145) со словарем объемом 40 тысяч термов [2];

- «ГОСТ»: 1066 длинных текстов (среднее количество термов в документе - 1391) со словарем объемом 23 тысяч термов (сформирован авторами).

Корпус «ГОСТ» был сформирован из документов, относящихся к категории нормативно-технических документов - государственных стандартов Российской Федерации (ГОСТов), и составлен на основе тематического классификатора ГОСТов. Каждый из документов этого корпуса является тематически однородным, у всех этих документов одинаковая (или похожая) структура, при этом в корпус объединены стандарты из разных тематических рубрик:

1. Безопасность (Безопасность в чрезвычайных ситуациях)

2. Геометрические параметры (Система обеспечения точности геометрических параметров в строительстве)

3. Грунты 
4. Дороги

5. ЕСКД (Единая система конструкторской документации)

6. Защита от коррозии

7. Защита от шума

8. Здания и сооружения

9. Изделия

10. Инструмент

11. Качество

12. Конструкции

13. Лифты

14. Материалы

15. Металлы

16. Оснастка и оборудование

17. Охрана природы

18. Разработка продукции (Система разработки и постановки продукции на производство)

19. СПДС (Система проектной документации для строительства)

20. СПКП (Система показателей качества продукции)

21. ССБТ (Система стандартов безопасности труда)

22. Средства защиты банковские

23. Стандартизация и патенты

24. Электроустановки

25. Энергетика нетрадиционная

26. Энергосбережение

27. Прочие

Документы корпуса «ГОСТ» находятся в свободном доступе на различных интернет-ресурсах в виде файлов разных форматов и могут быть собраны самостоятельно с учетом целей и ограничений конкретного исследования, как выборочно, так и с помощью скриптов для массовой загрузки файлов с сетевых информационных ресурсов.

Перечень документов, составляющих экспериментальный корпус «ГОСТ»:

1. ГОСТ Р 22.0.01-94 Безопасность в чрезвычайных ситуациях. Основные положения

2. ГОСТ Р 22.0.02-94 (с изм. 12000 ) Безопасность в чрезвычайных ситуациях. Термины и определения основных понятий

3. ГОСТ Р 22.0.05-94 Безопасность в чрезвычайных ситуациях. Техногенные чрезвычайные ситуации. Термины и определения

4. ГОСТ Р 22.0.06-95 Безопасность в чрезвычайных ситуациях. Поражающие факторы. Номенклатура параметров поражающих воздействий

5. ГОСТ Р 22.0.07-95 Безопасность в чрезвычайных ситуациях. Источники техногенных чрезвычайных ситуаций. Классификация и номенклатура поражающих факторов и их параметров

6. ГОСТ Р 22.0.08-96 Безопасность в чрезвычайных ситуациях. Техногенные чрезвычайные ситуации. Взрывы. Термины и определения

7. ГОСТ Р 22.0.10-96 (с изм. 1 2000) Безопасность в чрезвычайных ситуациях. Правила нанесения на карты обстановки о чрезвычайных ситуациях. Условные обозначения 
8. ГОСТ Р 22.0.11-99 Безопасность в чрезвычайных ситуациях. Предупреждение природных чрезвычайных ситуаций. Термины и определения

9. ГОСТ Р 22.1.01-95 Безопасность в чрезвычайных ситуациях. Мониторинг и прогнозирование. Основные положения

10. ГОСТ Р 22.1.02-95 Безопасность в чрезвычайных ситуациях. Мониторинг и прогнозирование. Термины и определения

11. ГОСТ Р 22.1.06-99 Безопасность в чрезвычайных ситуациях. Мониторинг и прогнозирование опасных геологических явлений и процессов. Общие требования

12. ГОСТ Р 22.1.07-99 Безопасность в чрезвычайных ситуациях. Мониторинг и прогнозирование опасных метеорологических явлений и процессов. Общие требования

13. ГОСТ Р 22.1.08-99 Безопасность в чрезвычайных ситуациях. Мониторинг и прогнозирование опасных гидрологических явлений и процессов. Общие требования

14. ГОСТ Р 22.1.09-99 Безопасность в чрезвычайных ситуациях. Мониторинг и прогнозирование лесных пожаров. Общие требования

15. ГОСТ Р 22.2.05-94 Безопасность в чрезвычайных ситуациях. Техногенные аварии и катастрофы. Нормируемые метрологические и точностные характеристики средств контроля и испытаний в составе сложных технических систем, формы и процедуры их метрологического обслуживания. Основные положения и правила

16. ГОСТ Р 22.2.07-94 Вещества взрывчатые инициирующие. Метод определения температуры вспышки

17. ГОСТ Р 22.6.01-95 Безопасность в чрезвычайных ситуациях. Защита систем хозяйственнопитьевого водоснабжения. Общие требования

18. ГОСТ Р 22.7.01-99 Безопасность в чрезвычайных ситуациях. Единая дежурно-диспетчерская служба. Основные положения

19. ГОСТ Р 22.8.05-99 Безопасность в чрезвычайных ситуациях. Аварийно-спасательные работы при ликвидации последствий аварий на химически опасных объектах. Общие требования

20. ГОСТ Р 22.8.06-99 Безопасность в чрезвычайных ситуациях. Аварийно-спасательные работы при ликвидации последствий аварий на радиационно опасных объектах. Общие требования

21. ГОСТ Р 22.8.07-99 Безопасность в чрезвычайных ситуациях. Аварийно-спасательные работы при ликвидации чрезвычайных ситуаций, вызванных опасными гидрологическими явлениями на акваториях. Общие требования

22. ГОСТ Р 22.9.01-95 Безопасность в чрезвычайных ситуациях. Аварийно-спасательный инструмент и оборудование. Общие технические требования

23. ГОСТ 21778-81 (1988) Система обеспечения точности геометрических параметров в строительстве. Основные положения

24. ГОСТ 21779-82 (СТ СЭВ 2681-80) (1993) Система обеспечения точности геометрических параметров в строительстве. Технологические допуски

25. ГОСТ 21780-83 (СТ СЭВ 3740-82) (1985) Система обеспечения точности геометрических параметров в строительстве. Расчет точности

26. ГОСТ 23615-79 (СТ СЭВ 5061-85) (1992) Система обеспечения точности геометрических параметров в строительстве. Статистический анализ точности

27. ГОСТ 23616-79 (СТ СЭВ 4234-83) (1992) Система обеспечения точности геометрических параметров в строительстве. Контроль точности

28. ГОСТ 26433.0-85 Система обеспечения точности геометрических параметров в строительстве. Правила выполнения измерений. Общие положения

29. ГОСТ 26433.1-89 Система обеспечения точности геометрических параметров в строительстве. Правила выполнения измерений. Элементы заводского изготовления

30. ГОСТ 26433.2-94 Система обеспечения точности геометрических параметров в строительстве. Правила выполнения измерений параметров зданий и сооружений

31. ГОСТ 26607-85 (СТ СЭВ 4416-83) Система обеспечения точности геометрических параметров в строительстве. Функциональные допуски

32. ГОСТ 28984-91 Модульная координация размеров в строительстве. Основные положения

33. ГОСТ 5180-84 Грунты. Методы лабораторного определения физических характеристик

34. ГОСТ 5686-94 Грунты. Методы полевых испытаний сваями

35. ГОСТ 12071-84 (1994) Грунты. Отбор, упаковка, транспортирование и хранение образцов

36. ГОСТ 12248-96 Грунты. Методы лабораторного определения характеристик прочности и деформируемости

37. ГОСТ 12536-79 Грунты. Методы лабораторного определения гранулометрического (зернового) и микроагрегатного состава

38. ГОСТ 19912-81 (1987) Грунты. Метод полевого испытания динамическим зондированием

39. ГОСТ 20069-81 Грунты. Метод полевого испытания статическим зондированием 
40. ГОСТ 20276-85 Грунты. Методы полевого определения характеристик деформируемости

41. ГОСТ 20522-96 Грунты. Методы статистической обработки результатов испытаний

42. ГОСТ 21719-80 Грунты. Методы полевых испытаний на срез в скважинах и в массиве

43. ГОСТ 22733-77 Грунты. Методы лабораторного определения максимальной плотности

44. ГОСТ 23061-90 Грунты. Методы радиоизотопных измерений плотности и влажности

45. ГОСТ 23161-78 Грунты. Метод лабораторного определения характеристик просадочности

46. ГОСТ 23253-78 Грунты. Методы полевых испытаний мерзлых грунтов

47. ГОСТ 23278-78 (1986) Грунты. Методы полевых испытаний проницаемости

48. ГОСТ 23740-79 (с попр. 1980) Грунты. Методы лабораторного определения содержания органических веществ

49. ГОСТ 23741-79 Грунты. Методы полевых испытаний на срез в горных выработках

50. ГОСТ 24143-80 (1987) Грунты. Метод лабораторного определения характеристик набухания и усадки

51. ГОСТ 24846-81 Грунты. Методы измерений деформаций оснований зданий и сооружений

52. ГОСТ 24847-81 (1987) Грунты. Метод определения глубины сезонного промерзания

53. ГОСТ 25100-95 Грунты. Классификация

54. ГОСТ 25358-82 Грунты. Метод полевого определения температуры

55. ГОСТ 25584-90 (с изм. 1 1999) Грунты. Методы лабораторного определения коэффициента фильтрации

56. ГОСТ 26262-84 Грунты. Метод полевого определения глубины сезонного оттаивания

57. ГОСТ 26263-84 Грунты. Метод лабораторного определения теплопроводности мерзлых грунтов

58. ГОСТ 27217-87 (1988) Грунты. Метод полевого определения удельных касательных сил морозного пучения

59. ГОСТ 28514-90 (СТ СЭВ 6016-87) Строительная геотехника. Определение плотности грунтов методом замещения объема

60. ГОСТ 28622-90 Грунты. Метод лабораторного определения степени пучинистости

61. ГОСТ 30416-96 Грунты. Лабораторные испытания. Общие положения

62. ГОСТ 30672-99 Грунты. Полевые испытания. Общие положения

63. ГОСТ 5865-51 (1955) Железные дороги узкоколейные наземные и подземные. Ширина колеи

64. ГОСТ 9720-76 (1995) Габариты приближения строений и подвижного состава железных дорог колеи 750 мм

65. ГОСТ 23961-80 Метрополитены. Габариты приближения строений, оборудования и подвижного состава

66. ГОСТ 24451-80 Тоннели автодорожные. Габариты приближения строений и оборудования

67. ГОСТ 26775-97 Габариты подмостовые судоходных пролетов мостов на внутренних водных путях. Нормы и технические требования

68. ГОСТ 30412-96 Дороги автомобильные и аэродромы. Методы измерений неровностей оснований и покрытий

69. ГОСТ 30413-96 Дороги автомобильные. Метод определения коэффициента сцепления колеса автомобиля с дорожным покрытием

70. ГОСТ Р 50597-93 Автомобильные дороги и улицы. Требования к эксплуатационному состоянию, допустимому по условиям обеспечения безопасности дорожного движения

71. СТ СЭВ 4940-84 Дороги автомобильные международные. Учет интенсивности движения

72. СТ СЭВ 5497-86 Дороги автомобильные международные. Определение несущей способности дорожных конструкций и их конструктивных слоев установкой динамического нагружения (УДН

73. ГОСТ 2.001-93 (1995) ЕСКД. Общие положения

74. ГОСТ 2.004-88 ЕСКД. Общие требования к выполнению конструкторских и технологических документов на печатающих и графических устройствах вывода ЭВМ

75. ГОСТ 2.101-68 (1995) ЕСКД. Виды изделий

76. ГОСТ 2.102-68 (1995) ЕСКД. Виды и комплектность конструкторских документов

77. ГОСТ 2.103-68 (1995) ЕСКД. Стадии разработки

78. ГОСТ 2.105-95 ЕСКД. Общие требования к текстовым документам

79. ГОСТ 2.106-96 ЕСКД. Текстовые файлы

80. ГОСТ 2.111-68 (1995) ЕСКД. Нормоконтроль

81. ГОСТ 2.114-95 ЕСКД. Технические условия 
82. ГОСТ 2.114-95 (2000, с поправкой 2000) ЕСКД. Технические условия

83. ГОСТ 2.118-73 (1995) ЕСКД. Техническое предложение

84. ГОСТ 2.119-73 (1995) ЕСКД. Эскизный проект

85. ГОСТ 2.120-73 (1995) ЕСКД. Технический проект

86. ГОСТ 2.123-93 (1995) ЕСКД. Комплектность конструкторских документов на печатные платы при автоматизированном проектировании

87. ГОСТ 2.320-82 (2000) ЕСКД. Правила нанесения размеров, допусков и посадок конусов

88. ГОСТ 2.503-90 (СТ СЭВ 1631-79, СТ СЭВ 4405-83) ЕСКД. Правила внесения изменений (взамен ГОСТ 2.503-74, ГОСТ 2.505-82, ГОСТ 2.506-84)

89. ГОСТ 2.601-95 ЕСКД. Эксплуатационные документы

90. ГОСТ 2.602-95 ЕСКД. Ремонтные документы

91. ГОСТ 2.701-84 (с изм. 1 1990, 2 1992) ЕСКД. Схемы. Виды и типы. Общие требования к выполнению

92. ГОСТ 2.705-70 ЕСКД. Правила выполнения электрических схем обмоток и изделий с обмотками

93. ГОСТ 2.780-96 ЕСКД. Обозначение условные графические. Кондиционеры рабочей среды, емкости гидравлические и пневматические

94. ГОСТ 2.784-96 ЕСКД. Обозначения условные графические. Элементы трубопроводов

95. ГОСТ Р 2.901-99 ЕСКД. Документация, отправляемая за границу

96. СТ СЭВ 1633-79 ЕСКД. Чертежи зданий и сооружений. Изображение вертикальных конструкций

97. СТ СЭВ 2825-80 ЕСКД. Чертежи строительные. Условные изображения и обозначения. Каналы дымовые и вентиляционные

98. СТ СЭВ 2826-80 ЕСКД. Чертежи строительные. Условные изображения и обозначения. Отверстия, ниши, пазы, борозды

99. СТ СЭВ 3506-81 ЕСКД. Чертежи строительные. Обозначения условные графические. Элементы водопровода

100.СТ СЭВ 3507-81 ЕСКД. Чертежи строительные. Обозначения условные графические. Элементы систем канализации

101.СТ СЭВ 4409-83 ЕСКД. Чертежи строительные. Правила выполнения чертежей деревянных конструкций

102.СТ СЭВ 4722-84 ЕСКД. Чертежи строительные. Условные изображения. Крепежные детали и отверстия на чертежах металлических конструкций

103.СТ СЭВ 4937-84 ЕСКД. Чертежи строительные. Каменные конструкции

104.ГОСТ 2.701-84 ЕСКД. Схемы. Виды и типы. Общие требования к выполнению.

105.ГОСТ 28574-90 (СТ СЭВ 6319-88) Защита от коррозии в строительстве. Конструкции бетонные и железобетонные. Методы испытаний адгезии защитных покрытий

106.ГОСТ 28575-90 (СТ СЭВ 6320-88) Защита от коррозии в строительстве. Конструкции бетонные и железобетонные. Испытание паропроницаемости защитных покрытий

107.СТ СЭВ 4419-83 Защита от коррозии в строительстве. Конструкции строительные. Термины и определения

108.СТ СЭВ 4420-83 Защита от коррозии в строительстве. Общие положения

109.СТ СЭВ 4421-83 Защита от коррозии в строительстве. Защитные свойства бетона по отношению к стальной арматуре. Электрохимический метод испытаний

110.СТ СЭВ 5980-87 Защита от коррозии в строительстве. Конструкции деревянные. Классификация агрессивных сред

111.ГОСТ 20444-85 (1994) Шум. Транспортные потоки. Методы измерения шумовой характеристики

112.ГОСТ 23337-78 (СТ СЭВ 2600-80) (1984) Шум. Методы измерения шума на селитебной территории и в помещениях жилых и общественных зданий

113.ГОСТ 23426-79 Шум. Методы измерения звукоизоляции кабин наблюдения и дистанционного управления в производственных зданиях

114.ГОСТ 23628-79 Шум. Методы измерения звукоизоляции кожухов

115.ГОСТ 27296-87 (СТ СЭВ 4866-84) (1988) Защита от шума в строительстве. Звукоизоляция ограждающих конструкций. Методы измерений

116.ГОСТ 27679-88 Защита от шума в строительстве. Санитарно-техническая арматура. Метод лабораторного измерения шума

117.ГОСТ 28100-89 (СТ СЭВ 6085-87) Защита от шума в строительстве. Глушители шума. Методы определения акустических характеристик

118.СТ СЭВ 4867-84 Защита от шума в строительстве. Звукоизоляция ограждающих конструкций. Нормы

119.ГОСТ 22853-86 Здания мобильные (инвентарные). Общие технические условия 
120.ГОСТ 23274-84 (с изм. 1 1990) Здания мобильные (инвентарные). Электроустановки. Общие технические условия

121.ГОСТ 23345-84 Здания мобильные (инвентарные). Системы санитарно-технические. Общие технические условия

122.ГОСТ 23838-89 Здания предприятий. Параметры (взамен ГОСТ 23837-79, ГОСТ 23838-79, ГОСТ 23839-79, ГОСТ 23840-79, ГОСТ 24336-80, ГОСТ 24337-80)

123.ГОСТ 24940-96 Здания и сооружения. Методы измерения освещенности

124.ГОСТ 25380-82 (1987) Здания и сооружения. Метод измерения плотности тепловых потоков, проходящих через ограждающие конструкции

125.ГОСТ 25891-83 Здания и сооружения. Методы определения сопротивления воздухопроницаемости ограждающих конструкций (в части лабораторных испытаний светопрозрачных конструкций и дверных блоков заменен ГОСТ 26602.2-99)

126.ГОСТ 25957-83 Здания и сооружения мобильные (инвентарные). Классификация. Термины и определения

127.ГОСТ 26253-84 (1987) Здания и сооружения. Метод определения теплоустойчивости ограждающих конструкций

128.ГОСТ 26254-84 (1994) Здания и сооружения. Методы определения сопротивления теплопередаче ограждающих конструкций

129.ГОСТ 26629-85 Здания и сооружения. Метод тепловизионного контроля качества теплоизоляции ограждающих конструкций

130.ГОСТ 26824-86 Здания и сооружения. Методы измерения яркости

131.ГОСТ 30494-96 Здания жилые и общественные. Параметры микроклимата в помещениях

132.СТ СЭВ 3976-83 Здания жилые и общественные. Основные положения проектирования

133.СТ СЭВ 3977-83 Здания производственные промышленных предприятий. Основные положения проектирования

134.ГОСТ 8747-88 (СТ СЭВ 5851-86) Изделия асбестоцементные листовые. Методы испытаний

135.ГОСТ 30301-95 Изделия асбестоцементные. Правила приемки

136.СТ СЭВ 4926-84 Изделия асбестоцементные. Термины и определения

137.СТ СЭВ 4927-84 Изделия асбестоцементные. Классификация

138.ГОСТ 538-88 (1993) (СТ СЭВ 5922-87) Изделия замочные и скобяные. Общие технические условия

139.ГОСТ 5087-80 (1993) Ручки для окон и дверей. Типы и основные размеры

140.ГОСТ 5088-94 Петли стальные для деревянных окон и дверей. Технические условия

141.ГОСТ 5089-97 Замки и защелки для дверей. Технические условия

142.ГОСТ 5090-86 (1993) Изделия скобяные запирающие для деревянных окон и дверей. Типы и основные размеры

143.ГОСТ 5091-78 (1987) Изделия скобяные вспомогательные для деревянных окон и дверей. Типы

144.ГОСТ 19091-82 (1999) Замки врезные и накладные цилиндровые и защелки врезные. Методы испытаний

145.ГОСТ 23306-87 (с изм. 1 1999) Замки врезные и накладные сувальдные для деревянных дверей. Методы испытаний

146.ГОСТ 27346-87 Изделия замочно-скобяные. Термины и определения

147.ГОСТ 15522-70 Гайки шестигранные низкие с уменьшенным размером "под ключ" класса точности В. Конструкция и размеры.

148.ГОСТ 15523-70 Гайки шестигранные высокие класса точности В. Конструкция и размеры.

149.ГОСТ 15524-70 Гайки шестигранные высокие класса точности А. Конструкция и размеры.

150.ГОСТ 15525-70 Гайки шестигранные особо высокие класса точности В. Конструкция и размеры.

151.ГОСТ 15589-70 (СТ СЭВ 4729-84) Болты с шестигранной головкой класса точности С. Конструкция и размер.

152.ГОСТ 15590-70 Болты с шестигранной уменьшенной головкой и направляющим подголовком класса точности С. Конструкция и размер.

153.ГОСТ 15591-70 Болты с шестигранной уменьшенной головкой класса точности С. Конструкция и paзмер.

154.ГОСТ 2524-70 Гайки шестигранные с уменьшенным размером "под ключ" класса точности А. Конструкция и размеры.

155.ГОСТ 5915-70 (СТ СЭВ 3683-82) Гайки шестигранные класса точности В. Конструкция и размеры.

156.ГОСТ 2526-70 Гайки шестигранные низкие с уменьшенным размером "под ключ" класса точности А. Конструкция и размеры. 
157.ГОСТ 3032-76 Гайки-барашки. Конструкция и размер.

158.ГОСТ 5916-70 (СТ СЭВ 3685-82) Гайки шестигранные низкие класса точности В. Конструкция и размеры.

159.ГОСТ 5927-70 (СТ СЭВ 3680-82) Гайки шестигранные класса точности А. Конструкция и размеры.

160.ГОСТ 5929-70 (СТ СЭВ 3681-82) Гайки шестигранные низкие класса точности А. Конструкция и размеры.

161.ГОСТ 5931-70 Гайки шестигранные особо высокие класса точности А. Конструкция и размеры.

162.ГОСТ 7795-70 Болты с шестигранной уменьшенной головкой и направляющим подголовком класса точности В. Конструкция и размер.

163.ГОСТ 7796-70 Болты с шестигранной уменьшенной головкой класса точности В. Конструкция и размер.

164.ГОСТ Р 51391-99 Изделия парфюмерно-косметические. Информация для потребителя. Общие требования.

165.ГОСТ 1153-76 (1993) Кронштейны для умывальников и моек. Технические условия

166.ГОСТ 1811-97 Трапы для систем канализации зданий. Технические условия

167.ГОСТ 6127-52 (1988) Краны банные. Технические условия

168.ГОСТ 8690-94 (попр. 1997) Радиаторы отопительные чугунные. Технические условия

169.ГОСТ 8870-79 Колонки водогрейные для ванн. Технические условия

170.ГОСТ 10944-75 (1995) Краны регулирующие для нагревательных приборов систем водяного отопления зданий

171.ГОСТ 11614-94 Краны смывные полуавтоматические. Технические условия

172.ГОСТ 13449-82 Изделия санитарные керамические. Методы испытаний

173.ГОСТ 15062-83 (1984, с изм. 1984, 1987, 1988) Сиденья для унитазов. Технические условия

174.ГОСТ 15167-93 (с изм. 1 1998) Изделия санитарные керамические. Общие технические условия

175.ГОСТ 18297-96 Приборы санитарно-технические чугунные эмалированные. Общие технические условия

176.ГОСТ 19681-94 Арматура санитарно-техническая водоразборная. Общие технические условия

177.ГОСТ 20849-94 Конвекторы отопительные. Технические условия

178.ГОСТ 21485-94 Бачки смывные и арматура к ним. Общие технические условия

179.ГОСТ 23289-94 Арматура санитарно-техническая водосливная. Технические условия

180.ГОСТ 23695-94 Приборы санитарно-технические стальные эмалированные. Технические условия

181.ГОСТ 25297-82 Установки компактные для очистки поверхностных вод на питьевые нужды. Типы, основные параметры и размеры

182.ГОСТ 25298-82 (1994) Установки компактные для очистки бытовых сточных вод. Типы, основные параметры и размеры

183.ГОСТ 25809-96 Смесители и краны водоразборные. Типы и основные размеры

184.ГОСТ 30493-96 Изделия санитарные керамические. Типы и основные размеры

185.ГОСТ Р 50851-96 (с попр. 1998) Мойки из нержавеющей стали. Технические условия

186.ГОСТ 12815-80 (1996) Фланцы арматуры, соединительных частей и трубопроводов на Ру от 0,1 до 20,0 МПа (от 1 до 200 кгс/см2). Типы. Присоединительные размеры и размеры уплотнительных поверхностей

187.ГОСТ 12816-80 (1996) Фланцы арматуры, соединительных частей и трубопроводов на Ру от 0,1 до 20,0 МПа (от 1 до 200 кгс/см2).Общие требования

188.ГОСТ 12817-80 (1996) Фланцы литые из серого чугуна на Ру от 0,1 до 1,6 МПа (от 1 до 16 кгс/см2). Конструкция и размеры

189.ГОСТ 862.1-85 Изделия паркетные. Паркет штучный. Технические условия

190.ГОСТ 862.2-85 Изделия паркетные. Паркет мозаичный. Технические условия

191.ГОСТ 862.3-86 Изделия паркетные. Доски паркетные. Технические условия

192.ГОСТ 862.4-87 (1994) Изделия паркетные. Щиты паркетные. Технические условия

193.ГОСТ 1598-75 (1987) Изделия огнеупорные шамотные для кладки доменных печей. Технические условия

194.ГОСТ 1598-96 Изделия огнеупорные шамотные для кладки доменных печей. Технические условия

195.ГОСТ 5091-78 (1987) Изделия скобяные вспомогательные для деревянных окон и дверей. Типы

196.ГОСТ 5742-76 (1995) Изделия из ячеистых бетонов теплоизоляционные 
197.ГОСТ 8242-88 (1996) Детали профильные из древесины и древесных материалов для строительства. Технические условия

198.ГОСТ 10499-95 Изделия теплоизоляционные из стеклянного штапельного волокна. Технические условия

199.ГОСТ 11047-90 Детали и изделия деревянные для малоэтажных жилых и общественных зданий. Технические условия

200.ГОСТ 15867-79 (с изм. 1 1983) Детали и изделия из древесины и древесных материалов. Метод определения прочности клеевого соединения на неравномерный отрыв облицовочных материалов

201.ГОСТ 19111-77 (1992) Изделия погонажные профильные поливинилхлоридные. Технические условия

202.ГОСТ 22406-77 (1987) Детали и изделия из древесины для строительства. Метод определения условной влагопроницаемости влагозащитных покрытий и пропиток

203.ГОСТ 22546-77 (1988) Изделия теплоизоляционные из пенопласта ФРП-1. Технические условия

204.ГОСТ 23342-91 Изделия архитектурно-строительные из природного камня. Технические условия

205.ГОСТ 25535-82 Изделия из стекла. Методы определения термической стойкости

206.ГОСТ 17375-83 Группа Г18 Детали трубопроводов стальные бесшовные приварные. Отводы крутоизогнутые.

207.ГОСТ 7948-80 (1994) Отвесы стальные строительные. Технические условия

208.ГОСТ 9416-83 (1994) Уровни строительные. Технические условия

209.ГОСТ 9533-81 (1993) Кельмы, лопатки и отрезовки. Технические условия

210.ГОСТ 10597-87 (1994) Кисти и щетки малярные. Технические условия

211.ГОСТ 10831-87 (1993) Валики малярные. Технические условия

212.ГОСТ 11042-90 (1993) Молотки стальные строительные. Технические условия

213.ГОСТ 25782-90 Правила, терки и полутерки. Технические условия

214.ГОСТ Р ИСО 9001-96 Системы качества. Модель обеспечения качества при проектировании, разработке, производстве, монтаже и обслуживании

215.ГОСТ Р ИСО 9002-96 Системы качества. Модель обеспечения качества при производстве, монтаже и обслуживании

216.ГОСТ Р ИСО 9003-96 Системы качества. Модель обеспечения качества при окончательном контроле и испытаниях

217.ГОСТ Р ИСО 10011-1-93 Руководящие указания по проверке систем качества. Часть 1. Проверка

218.ГОСТ Р ИСО 10011-2-93 Руководящие указания по проверке систем качества. Часть 2. Квалификационные критерии для экспертов аудиторов

219.ГОСТ Р ИСО 10011-3-93 Руководящие указания по проверке систем качества. Часть 3. Руководство программой проверок

220.ИСО 9000-1-94 (1996) Общее руководство качеством и стандарты по обеспечению качества. Часть 1. Руководящие указания по выбору и применению

221.ИСО 9000-2-93 Стандарты в области административного управления качеством и обеспечения качества. Часть 2. Общие руководящие указания по применению стандартов ИСО 9001, ИСО 9002 и ИСО 9003

222.ИСО 9000-3-91 Стандарты в области административного управления качеством и обеспечения качества. Часть 3. Руководящие указания по применению стандарта ИСО 9001 при разработке, поставке и обслуживании программного обеспечения

223.ИСО 9000-4-93 (МЭК 300-1)

224.ИСО 9004-1-94 Управление качеством и элементы системы качества. Часть 1. Руководящие указания

225.ИСО 9004-2-91 Административное управление качеством и элементы системы качества. Часть 2. Руководящие указания по услугам

226.ИСО 9004-3-93 Административное управление качеством и элементы системы качества. Часть 3. Руководящие указания по обработанным материалам

227.ИСО 9004-4-93 Административное управление качеством и элементы системы качества. Часть 4. Руководящие указания по улучшению качества

228.ИСО 10005-95 Административное управление качеством. Руководящие указания по программам качества

229.ИСО 10007-95 Административное управление качеством. Руководящие указания по управлению конфигурацией

230.ИСО 10013-95 Руководящие указания по разработке руководств по качеству 
231.ГОСТ Р ИСО 9004-2001 Системы менеджмента качества. Рекомендации по улучшению деятельности.

232.ГОСТ Р ИСО 9000-2001 Системы менеджмента качества. Основные положения и словарь.

233.ГОСТ Р ИСО 9001-2001 Системы менеджмента качества. Требования.

234.ГОСТ 15467-79 (СТ СЭВ 3519-81) Управление качеством продукции. Основные понятия. Термины и определения.

235.ГОСТ 5781-82 (1993, с поправкой 1994) Сталь горячекатаная для армирования железобетонных конструкций. Технические условия

236.ГОСТ 6727-80 (1998) Проволока из низкоуглеродистой стали холоднотянутая для армирования железобетонных конструкций. Технические условия

237.ГОСТ 10884-94 Сталь арматурная термомеханически упрочненная для железобетонных конструкций. Технические условия

238.ГОСТ 10922-90 Арматурные и закладные изделия сварные, соединения сварные арматуры и закладных изделий железобетонных конструкций. Общие технические условия

239.ГОСТ 12004-81 (1995) Сталь арматурная. Методы испытания на растяжение

240.ГОСТ 14098-91 Соединения сварные арматуры и закладных изделий железобетонных конструкций. Типы, конструкции и размеры

241.ГОСТ 21924.3-84 (с изм 1 1988) Плиты железобетонные для покрытий городских дорог. Арматурные и монтажно-стыковые изделия. Конструкция и размеры

242.ГОСТ 22362-77 (1988) Конструкции железобетонные. Методы измерения силы натяжения арматуры

243.ГОСТ 23117-91 Зажимы полуавтоматические для натяжения арматуры железобетонных конструкций. Технические условия

244.ГОСТ 23279-85 (1987) Сетки арматурные сварные для железобетонных конструкций и изделий. Общие технические условия

245.ГОСТ 23858-79 (1995) Соединения сварные стыковые и тавровые арматуры железобетонных конструкций. Ультразвуковые методы контроля качества. Правила приемки

246.ГОСТ 25912.4-91 Арматурные и монтажно-стыковые изделия железобетонных плит для аэродромных покрытий. Конструкция

247.ГОСТ 30062-93 Арматура стержневая для железобетонных конструкций. Вихретоковый метод контроля прочностных характеристик

248.ГОСТ 4981-87 Балки перекрытий деревянные. Технические условия

249.ГОСТ 20372-90 Балки стропильные и подстропильные железобетонные. Технические условия

250.ГОСТ 23121-78 Балки подкрановые стальные для мостовых электрических кранов общего назначения грузоподъемностью до 50 т. Технические условия

251.ГОСТ 24893.0-81 (1988) Балки обвязочные железобетонные для зданий промышленных предприятий. Технические условия

252.ГОСТ 28737-90 Балки фундаментные железобетонные для стен зданий промышленных и сельскохозяйственных предприятий. Технические условия

253.ГОСТ 9272-81 (с изм. 1 1983, с изм. 2 1985, с попр. 1989) Блоки стеклянные пустотелые. Технические условия

254.ГОСТ 13579-78 (1994) Блоки бетонные для стен подвалов. Технические условия

255.ГОСТ 17079-88 (с попр. 1990) Блоки вентиляционные железобетонные. Технические условия

256.ГОСТ 19010-82 (1993) Блоки стеновые бетонные и железобетонные для зданий. Общие технические условия

257.ГОСТ 21520-89 Блоки из ячеистых бетонов стеновые мелкие. Технические условия

258.ГОСТ 475-78 (1991) Двери деревянные. Общие технические условия

259.ГОСТ 6629-88 Двери деревянные внутренние для жилых и общественных зданий. Типы и конструкция

260.ГОСТ 11214-86 Окна и балконные двери деревянные с двойным остекленением для жилых и общественных зданий. Типы, конструкция и размеры

261.ГОСТ 12506-81 Окна деревянные для производственных зданий. Типы, конструкция и размеры

262.ГОСТ 14624-84 (1996) Двери деревянные для производственных зданий. Типы, конструкции и размеры

263.ГОСТ 16289-86 (1996) Окна и балконные двери деревянные с тройным остекленением для жилых и общественных зданий. Типы, конструкция и размеры

264.ГОСТ 18853-73 (1984) Ворота деревянные распашные для производственных зданий и сооружений. Технические условия

265.ГОСТ 21519-84 (1992) Окна и двери балконные, витрины и витражи из алюминиевых сплавов. Общие технические условия 
266.ГОСТ 23166-78 (с изм. 1987) Окна и балконные двери деревянные. Общие технические условия

267.ГОСТ 23344-78 (1995) Окна стальные. Общие технические условия

268.ГОСТ 23747-88 (1990) Двери из алюминиевых сплавов. Общие технические условия

269.ГОСТ 24033-80 (1987) Окна и балконные двери деревянные. Методы механических испытаний

270.ГОСТ 24698-81 Двери деревянные наружние для жилых и общественных зданий. Типы, конструкции и размеры

271.ГОСТ 24699-81 Окна и балконные двери деревянные со стеклопакетами и стеклами для жилых и общественных зданий. Типы, конструкция и размеры

272.ГОСТ 24700-81 Окна и балконные двери деревянные со стеклопакетами для жилых и общественных зданий. Типы, конструкция и размеры

273.ГОСТ 25097-82 (1996) Окна и балконные двери деревоалюминиевые. Общие технические условия

274.ГОСТ 26601-85 Окна и балконные двери деревянные для малоэтажных жилых домов. Типы, конструкция и размеры

275.ГОСТ 26602.1-99 Блоки оконные и дверные. Методы определения сопротивления теплопередаче (взамен ГОСТ 26602-85, СТ СЭВ 4183-83)

276.ГОСТ 26602.2-99 Блоки оконные и дверные. Методы определения воздухо- и водопроницаемости (взамен ГОСТ 25891-83 в части лабораторных испытаний светопрозрачных конструкций и дверных блоков, ГОСТ 28799-90 (СТ СЭВ 6528-88), СТ СЭВ 4184-83)

277.ГОСТ 26602.3-99 Блоки оконные и дверные. Метод определения звукоизоляции

278.ГОСТ 26602.4-99 Блоки оконные и дверные. Метод определения общего коэффициента пропускания света

279.ГОСТ 26892-86 Двери деревянные. Метод испытания на сопротивление ударной нагрузке, действующей в направлении открывания

280.ГОСТ 27936-88 (1996) Окна и двери балконные деревоалюминиевые для общественных зданий. Типы и конструкция

281.ГОСТ 28786-90 (СТ СЭВ 6529-88) Двери деревянные. Метод определения сопротивления воздействию климатических факторов

282.ГОСТ 30109-94 Двери деревянные. Методы испытаний на сопротивление взлому

283.ГОСТ 30247.2-97 Конструкции строительные. Методы испытаний на огнестойкость. Двери и ворота.

284.ГОСТ 30673-99 Профили поливинилхлоридные для оконных и дверных блоков. Технические условия

285.СТ СЭВ 3285-81 Двери деревянные. Методы испытания надежности

286.СТ СЭВ 4180-83 Двери деревянные. Метод испытания сопротивления ударной нагрузке

287.СТ СЭВ 4181-83 Двери деревянные. Метод определения плоскостности

288.ГОСТ 24700-99 Блоки оконные деревянные со стеклопакетами. Технические условия.

289.ГОСТ 1005-86 (1991) Щиты перекрытий деревянные для малоэтажных домов технические условия

290.ГОСТ 17005-82 Конструкции деревянные клееные. Метод определения водостойкости клеевых соединений

291.ГОСТ 17580-82 Конструкции деревянные клееные. Метод определения стойкости клеевых соединений к цикличным температурно-влажностным воздействиям

292.ГОСТ 20850-84 (1987) Конструкции деревянные клееные. Общие технические условия

293.ГОСТ 25884-83 Конструкции деревянные клееные. Метод определения прочности клеевых соединений при послойном скалывании

294.ГОСТ 25885-83 Конструкции деревянные клееные. Метод определения прочности клеевых соединений древесноплитных материалов с древесиной

295.ГОСТ 28015-89 (1996) Щиты покрытий пола деревянные однослойные. Технические условия

296.ГОСТ 5172-63 Газгольдеры стальные постоянного объема, цилиндрические. Параметры и основные размеры

297.ГОСТ 17032-71 (1992) Резервуары стальные горизонтальные для нефтепродуктов. Типы и основные параметры

298.ГОСТ 22233-93 Профили прессованные из алюминиевых сплавов для ограждающих строительных конструкций. Общие технические условия

299.ГОСТ 23118-78 Конструкции металлические строительные. Общие технические условия

300.ГОСТ 23119-78 (1979) Фермы стропильные стальные сварные с элементами из парных уголков для производственных зданий. Технические условия 
301.ГОСТ 23120-78 (1992) Лестницы маршевые, площадки и ограждения стальные. Технические условия

302.ГОСТ 23682-79 Колонны стальные ступенчатые для зданий с мостовыми электрическими кранами общего назначения грузоподъемностью до 50 т. Технические условия

303.ГОСТ 24767-81 (1991) Профили холодногнутые из алюминия и алюминиевых сплавов для ограждающих строительных конструкций. Технические условия

304.ГОСТ 24839-81 (1986) Конструкции строительные стальные. Расположение отверстий в прокатных профилях. Размеры

305.ГОСТ 25772-83 Ограждения лестниц, балконов и крыш стальные. Общие технические условия

306.ГОСТ 26047-83 (1991) Конструкции строительные стальные. Условные обозначения (марки)

307.ГОСТ 26429-85 (с попр. 1987) Конструкции стальные путей подвесного транспорта. Технические условия

308.ГОСТ 26804-86 (1996) Ограждения дорожные металлические барьерного типа. Технические условия

309.СТ СЭВ 3972-83 Надежность строительных конструкций и оснований. Конструкции стальные. Основные положения по расчету

310.СТ СЭВ 3973-83 Надежность строительных конструкций и оснований. Конструкции алюминиевые. Основные положения по расчету

311.ГОСТ 19330-91 Стойки железобетонные для опор контактной сети железных дорог. Технические условия

312.ГОСТ 19330-99 Стойки железобетонные для опор контактной сети железных дорог. Технические условия

313.ГОСТ 22687.0-85 (с изм. 1 1986) Стойки железобетонные центрифугированные для опор высоковольтных линий электропередачи. Технические условия (взамен ГОСТ 22687-77, ГОСТ 24762-81)

314.ГОСТ 22131-76 (1979) Опоры железобетонные высоковольтно-сигнальных линий автоблокировки железных дорог. Технические условия

315.ГОСТ 22687.3-85 Стойки железобетонные центрифугированные для опор высоковольтных линий электропередачи. Конструкция закладных изделий и подпятников

316.ГОСТ 23444-79 (1988) Стойки железобетонные центрифугированные кольцевого сечения для производственных зданий и инженерных сооружений. Технические условия

317.ГОСТ 25458-82 Опоры деревянные дорожных знаков. Технические условия

318.ГОСТ 25459-82 (1987) Опоры железобетонные дорожных знаков. Технические условия

319.ГОСТ 9574-90 Панели гипсобетонные для перегородок. Технические условия

320.ГОСТ 11024-84 (1992) Панели стеновые наружные бетонные и железобетонные для жилых и общественных зданий. Общие технические условия

321.ГОСТ 11118-73 (1979) Панели из автоклавных ячеистых бетонов для наружных стен зданий. Технические требования

322.ГОСТ 12504-80 (1992) Панели стеновые внутренние бетонные и железобетонные для жилых и общественных зданий. Общие технические условия

323.ГОСТ 13578-68 (1994) Панели из легких бетонов на пористых заполнителях для наружных стен производственных зданий. Технические требования

324.ГОСТ 18128-82 (1986) Панели асбестоцементные стеновые наружние на деревянном каркасе с утеплителем. Технические условия

325.ГОСТ 19570-74 Панели из автоклавных ячеистых бетонов для внутренних несущих стен, перегородок и перекрытий для жилых и общественных зданий. Технические требования

326.ГОСТ 21096-75 Панели оконные стальные из горячекатанных и гнутых профилей для производственных зданий

327.ГОСТ 21562-76 Панели металлические с утеплителем из пенопласта. Общие технические условия

328.ГОСТ 22695-77 (1987) Панели стен и покрытий слоистые из пенопластов. Пенопласты. Методы испытаний на прочность

329.ГОСТ 23404-86 Панели легкие ограждающие с утеплителем из пенопласта. Метод определения модулей упругости и сдвига пенопласта

330.ГОСТ 23486-79 (1986) Панели металлические трехслойные с утеплителем из пенополиуретана. Технические условия

331.ГОСТ 24434-80 (1988) Панели слоистые с утеплителем из пенопластов для стен и покрытий зданий. Пенопласты. Метод определения усадки

332.ГОСТ 24524-80 (1987) Панели стальные двухслойные покрытий зданий с утеплителем из пенополиуретана. Технические условия

333.ГОСТ 24581-81 Панели асбестоцементные трехслойные с утеплителем из пенопласта. Общие технические условия 
334.ГОСТ 24594-81 Панели и блоки стеновые из кирпича и керамических камней. Общие технические условия

335.ГОСТ 25098-87 Панели перегородок железобетонные для зданий промышленных и сельскохозяйственных предприятий. Технические условия

336.ГОСТ 4598-86 (1997) Плиты древесноволокнистые. Технические условия

337.ГОСТ 8904-81 (1983) Плиты древесноволокнистые твердые с лакокрасочным покрытием. Технические условия

338.ГОСТ 19592-80 (СТ СЭВ 6011-87, 6012-87, 6013-87, 1771-79, 1772-79, 1773-79) (1987) Плиты древесноволокнистые. Методы испытаний

339.ГОСТ 26988-86 (1992) Плиты древесноволокнистые. Метод определения предела прочности при растяжении перпендикулярно пласти плиты

340.ГОСТ 27935-88 Плиты древесноволокнистые и древесностружечные. Термины и определения

341.ГОСТ 9573-96 Плиты из минеральной ваты на синтетическом связующем теплоизоляционные. Технические условия

342.ГОСТ 10140-80 (1983) Плиты теплоизоляционные из минеральной ваты на битумном связующем. Технические условия

343.ГОСТ 15588-86 (1987) Плиты пенополистирольные. Технические условия

344.ГОСТ 16136-80 (1990) Плиты перлитобитумные теплоизоляционные. Технические условия

345.ГОСТ 20916-87 (с попр. 1989) Плиты теплоизоляционные из пенопласта на основе резольных феноло-формальдегидных смол. Технические условия

346.ГОСТ 21880-94 (с изм. 1 1997) Маты прошивные из минеральной ваты теплоизоляционные. Технические условия

347.ГОСТ 22950-95 Плиты минераловатные повышенной жесткости на синтетическом связующем. Технические условия

348.ГОСТ 23307-78 (1991) (СТ СЭВ 5850-86) Маты теплоизоляционные из минеральной ваты вертикально-слоистые. Технические условия

349.ГОСТ 6428-83 (попр. 1986, 1989) Плиты гипсовые для перегородок. Технические условия

350.ГОСТ 6785-80 (1981, с попр. 1982) Плиты подоконные железобетонные. Технические условия (взамен ГОСТ 6785-69 и ГОСТ 8484-71 в части типов и основных размеров плит, заменен ГОСТ 26919-86 в части плит для жилых, общественных и вспомогательных зданий)

351.ГОСТ 6927-74 Плиты бетонные фасадные. Технические требования

352.ГОСТ 8484-82 (1990) Плиты подоконные железобетонные для производственных зданий. Конструкция и размеры

353.ГОСТ 9480-89 (1992) Плиты облицовочные из природного камня. Технические условия

354.ГОСТ 9561-91 Плиты перекрытий железобетонные многопустотные для зданий и сооружений. Технические условия

355.ГОСТ 12767-94 Плиты перекрытий железобетонные сплошные для крупнопанельных зданий. Общие технические условия

356.ГОСТ 13580-85 (1994) Плиты железобетонные ленточных фундаментов. Технические условия

357.ГОСТ 17608-91 (с изм. 1 1997) Плиты бетонные тротуарные. Технические условия

358.ГОСТ 19231.0-83 (1984) Плиты железобетонные для покрытий трамвайных путей. Общие технические условия

359.ГОСТ 19231.1-83 (1984) Плиты железобетонные для покрытий трамвайных путей. Конструкция и размеры

360.ГОСТ 21506-87 (1991) Плиты перекрытий железобетонные высотой 300 мм для зданий и сооружений. Технические условия

361.ГОСТ 21924.0-84 (с изм 1 1988) Плиты железобетонные для покрытий городских дорог. Технические условия

362.ГОСТ 21924.1-84 (с изм 1 1988) Плиты железобетонные предварительно-напряженные для покрытий городских дорог. Конструкция и размеры

363.ГОСТ 21924.2-84 (с изм 1 1988) Плиты железобетонные с ненапрягаемой арматурой для покрытий городских дорог. Конструкция и размеры

364.ГОСТ 22930-87 (с попр. 1988) Плиты железобетонные предварительно напряженные для облицовки оросительных каналов мелиоративных систем

365.ГОСТ 24099-80 (1992) Плиты декоративные на основе природного камня. Технические условия

366.ГОСТ 25697-83 (1989) Плиты балконов и лоджий железобетонные. Общие технические условия

367.ГОСТ 25912.0-91 Плиты железобетонные предварительно напряженные ПАГ для аэродромных покрытий. Технические условия

368.ГОСТ 25912.1-91 Плиты железобетонные предварительно напряженные ПАГ-14 для аэродромных покрытий. Конструкция 
369.ГОСТ 25912.2-91 Плиты железобетонные предварительно напряженные ПАГ-18 для аэродромных покрытий. Конструкция

370.ГОСТ 25912.3-91 Плиты железобетонные предварительно напряженные ПАГ-20 для аэродромных покрытий. Конструкция

371.ГОСТ 26434-85 Плиты перекрытий железобетонные для жилых зданий. Типы и основные параметры ( с 01.01.92 частично заменен ГОСТ 9561-91)

372.ГОСТ 26816-86 (с попр. 1987) Плиты цементностружечные. Технические условия

373.ГОСТ 26919-86 Плиты подоконные железобетонные для жилых, общественных и вспомогательных зданий. Технические условия)

374.ГОСТ 27215-87 Плиты перекрытий железобетонные ребристые высотой 400 мм для производственных зданий промышленных предприятий. Технические условия

375.ГОСТ 28042-89 (с поправками 1990, 1991) Плиты покрытий железобетонные для зданий предприятий. Технические условия

376.ГОСТ 19804-91 (1995) Сваи железобетонные. Технические условия (взамен ГОСТ 19804.0-78)

377.ГОСТ 19804.2-79 (1995) Сваи забивные железобетонные цельные сплошные квадратного сечения с поперечным армированием ствола с напрягаемой арматурой. Конструкции и размеры

378.ГОСТ 19804.3-80 (1986) Сваи забивные железобетонные квадратного сечения с круглой полостью. Конструкции и размеры

379.ГОСТ 19804.4-78 (1983) Сваи забивные железобетонные квадратного сечения без поперечного армирования ствола. Конструкции и размеры

380.ГОСТ 19804.5-83 Сваи полые круглого сечения и сваи-оболочки железобетонные цельные с ненапрягаемой арматурой. Конструкции и размеры

381.ГОСТ 19804.6-83 (1992) Сваи полые круглого сечения и сваи-оболочки железобетонные составные с ненапрягаемой арматурой. Конструкции и размеры

382.ГОСТ 539-80 (1997) Трубы и муфты асбестоцементные напорные. Технические условия

383.ГОСТ 1839-80 Трубы и муфты асбестоцементные для безнапорных трубопроводов. Технические условия

384.ГОСТ 6482-88 Трубы железобетонные безнапорные. Технические условия

385.ГОСТ 11310-90 (СТ СЭВ 6318-88) Трубы и муфты асбестоцементные. Методы испытаний

386.ГОСТ 12586.0-83 (1994) Трубы железобетонные напорные виброгидропрессованные. Технические условия

387.ГОСТ 12586.1-83 (1994) Трубы железобетонные напорные виброгидропрессованные. Конструкция и размеры

388.ГОСТ 20054-82 (1992) Трубы бетонные безнапорные. Технические условия

389.ГОСТ 22000-86 (1989) Трубы бетонные и железобетонные. Типы и основные параметры

390.ГОСТ 24547-81 (1991) Звенья железобетонные водопропускных труб под насыпи автомобильных и железных дорог. Общие технические условия

391.ГОСТ 24983-81 (с изм. 1 1991) Трубы железобетонные напорные. Ультразвуковой метод контроля и оценки трещиностойкости

392.ГОСТ 26067.0-83 Звенья железобетонные безнапорных труб прямоугольного сечения для гидротехнических сооружений. Технические условия

393.ГОСТ 26067.1-83 Звенья железобетонные безнапорных труб прямоугольного сечения для гидротехнических сооружений. Конструкции и размеры

394.ГОСТ 26819-86 (с изм. 1 1989, попр. 1990 ) Трубы железобетонные напорные со стальным сердечником. Технические условия

395.ГОСТ 948-84 (1991) Перемычки железобетонные железобетонные для зданий с кирпичными стенами. Технические условия

396.ГОСТ 5742-76 (1995) Изделия из ячеистых бетонов теплоизоляционные

397.ГОСТ 8020-90 (с попр. 1991) Конструкции бетонные и железобетонные для колодцев канализационных, водопроводных и газопроводных сетей. Технические условия

398.ГОСТ 8717.0-84 (1987) Ступени железобетонные и бетонные. Технические условия

399.ГОСТ 8717.1-84 (1987) Ступени железобетонные и бетонные. Конструкции и размеры

400.ГОСТ 8829-94 Изделия строительные железобетонные и бетонные заводского изготовления. Методы испытаний нагружением. Правила оценки прочности, жесткости и трещиностойкости

401.ГОСТ 9818-85 (1989) Марши и площадки лестниц железобетонные. Технические условия

402.ГОСТ 10629-88 (с попр 1990) Шпалы железобетонные, предварительно напряженные для железных дорог колеи 1520 мм. Технические условия

403.ГОСТ 13015.0-83 (1989) Конструкции и изделия бетонные и железобетонные сборные. Общие технические требования 
404.ГОСТ 13015.1-81 (1989) Конструкции и изделия бетонные и железобетонные сборные. Приемка 405.ГОСТ 13015.2-81 (1989) Конструкции и изделия бетонные и железобетонные сборные. Маркировка

406.ГОСТ 13015.3-81 (1989) Конструкции и изделия бетонные и железобетонные сборные. Документ о качестве

407.ГОСТ 13015.4-84 (1989) Конструкции и изделия бетонные и железобетонные сборные. Правила транспортировки и хранения

408.ГОСТ 17538-82 (1999) Конструкции и изделия железобетонные для шахт лифтов жилых зданий. Технические условия

409.ГОСТ 17625-83 (1987) Конструкции и изделия железобетонные. Радиационный метод определения толщины защитного слоя бетона, размеров и расположения арматуры

410.ГОСТ 18048-80 (1999) Кабины санитарно-технические железобетонные. Технические условия

411.ГОСТ 18979-90 Колонны железобетонные для многоэтажных зданий. Технические условия

412.ГОСТ 18980-90 Ригели железобетонные для многоэтажных зданий. Технические условия

413.ГОСТ 20182-74 (1988) Конструкции асбестоцементные клееные. Метод определения прочности клеевых соединений при сдвиге

414.ГОСТ 20213-89 Фермы железобетонные. Технические условия

415.ГОСТ 20425-75 (1988) Тетраподы для берегозащитных и оградительных сооружений

416.ГОСТ 21174-75 (1987) Шпалы железобетонные предварительно напряженные для трамвайных путей широкой колеи

417.ГОСТ 21509-76 (1984) Лотки железобетонные оросительных систем. Технические условия

418.ГОСТ 22904-93 Конструкции железобетонные. Магнитный метод определения толщины защитного слоя бетона и расположения арматуры

419.ГОСТ 23009-78 (1990) Конструкции и изделия бетонные и железобетонные сборные. Условные обозначения (марки)

420.ГОСТ 23899-79 Колонны железобетонные под параболические лотки. Технические условия

421.ГОСТ 23972-80 Фундаменты железобетонные для параболических лотков. Технические условия

422.ГОСТ 24022-80 Фундаменты железобетонные сборные под колонны сельскохозяйственных зданий. Технические условия

423.ГОСТ 24155-80 Конструкции железобетонные высоких пассажирских платформ. Технические условия

424.ГОСТ 24476-80 (1989) Фундаменты железобетонные сборные под колонны каркаса межвидового применения для многоэтажных зданий. Технические условия

425.ГОСТ 8823-85 (СТ СЭВ 4326-83) (с поправками 1986, 1987) Лифты электрические грузовые. Основные параметры и размеры (взамен ГОСТ 8823-67, ГОСТ 9322-67, ГОСТ 13415-67, ГОСТ 13416-67)

426.ГОСТ 8824-84 (СТ СЭВ 4326-83) (с изм. 1 1986) Лифты электрические грузовые малые. Основные параметры и размеры

427.ГОСТ 22011-95 Лифты пассажирские и грузовые. Технические условия

428.ГОСТ 22845-85 (1991) Лифты электрические пассажирские и грузовые. Правила организации, производства и приемки монтажных работ

429.ГОСТ 26334-84 (СТ СЭВ 4324-83) Лифты электрические. Ряды грузоподъемности и скорости

430.ГОСТ 28911-98 Лифты и грузовые малые лифты. Устройства управления, сигнализации и дополнительные приспособления

431.ГОСТ Р 51630-2000 Платформы подъемные с вертикальным и наклонным перемещением для инвалидов. Технические требования доступности

432.ГОСТ Р 51631-2000 Лифты пассажирские. Технические требования доступности для инвалидов

433.СТ СЭВ 291-76 Техника безопасности. Лифты электрические. Паспорт

434.СТ СЭВ 632-77 Техника безопасности. Лифты электрические. Графические символы

435.СТ СЭВ 726-85 Техника безопасности. Лифты электрические. Требования к кабине, противовесу, направляющим

436.ГОСТ 5802-86 (с попр. 1989) Растворы строительные. Методы испытаний

437.ГОСТ 7473-94 Смеси бетонные.Технические условия

438.ГОСТ 9128-97 (с попр. 1999) Смеси асфальтобетонные дорожные, аэродромные и асфальтобетон. Технические условия

439.ГОСТ 10060.0-95 Бетоны. Методы определения морозостойкости. Общие требования

440.ГОСТ 10060.1-95 Бетоны. Базовый метод определения морозостойкости 
441.ГОСТ 10060.2-95 Бетоны. Ускоренные методы определения морозостойкости при многовариантном замораживании и оттаивании

442.ГОСТ 10060.3-95 Бетоны. Дилатометрический метод ускоренного определения морозостойкости

443.ГОСТ 10060.4-95 Бетоны. Структурно-механический метод ускоренного определения морозостойкости

444.ГОСТ 10180-90 Бетоны. Методы определения прочности по контрольным образцам

445.ГОСТ 10181.0-81 Смеси бетонные. Общие требования к методам испытаний

446.ГОСТ 10181.1-81 Смеси бетонные. Методы определения удобоукладываемости

447.ГОСТ 10181.2-81 Смеси бетонные. Методы определения плотности

448.ГОСТ 10181.3-81 Смеси бетонные. Методы определения пористости

449.ГОСТ 10181.4-81 Смеси бетонные. Методы определения расслаиваемости

450.ГОСТ 12730.0-78 (1994) Бетоны. Общие требования к методам определения плотности, влажности, водопоглощения, пористости и водонепроницаемости

451.ГОСТ 12730.1-78 (1994) Бетоны. Методы определения плотности

452.ГОСТ 12730.2-78 (1994) Бетоны. Метод определения влажности

453.ГОСТ 12730.3-78 (1994) Бетоны. Метод определения водопоглощения

454.ГОСТ 12730.4-78 (1994) Бетоны. Методы определения показателен пористости

455.ГОСТ 12730.5-84 (1994) Бетоны. Методы определения водопроницаемости

456.ГОСТ 12852.0-77 Бетон ячеистый. Общие требования к методам испытаний

457.ГОСТ 12852.5-77 Бетон ячеистый. Метод определения коэффициента паропроницаемости

458.ГОСТ 12852.6-77 Бетон ячеистый. Метод определения сорбционной влажности

459.ГОСТ 13087-81 Бетоны. Методы определения истираемости

460.ГОСТ 17623-87 Бетоны. Радиоизотопный метод определения средней плотности

461.ГОСТ 17624-87 (с попр. 1989) Бетоны. Ультразвуковой метод определения прочности

462.ГОСТ 18105-86 (1992, с изм. 1 1987) Бетоны. Правила контроля прочности

463.ГОСТ 20910-90 Бетоны жаростойкие. Технические условия

464.ГОСТ 22685-89 Формы для изготовления контрольных образцов бетона. Технические условия

465.ГОСТ 22690-88 (1989) Бетоны. Определение прочности механическими методами неразрушающего контроля

466.ГОСТ 22783-77 Бетоны. Метод ускоренного определения прочности на сжатие

467.ГОСТ 23732-79 (1993) Вода для бетонов и растворов. Технические условия

468.ГОСТ 24211-91 Добавки для бетонов. Общие технические условия

469.ГОСТ 24316-80 (с попр. 1982) Бетоны. Метод определения тепловыделения при твердении

470.ГОСТ 24452-80 Бетоны. Методы испытаний

471.ГОСТ 24544-81 (1987) Бетоны. Методы определения деформаций усадки и ползучести

472.ГОСТ 24545-81 (1989) Бетоны. Методы испытаний на выносливость

473.ГОСТ 25192-82 (1991) Бетоны. Классификация и общие технические требования

474.ГОСТ 25214-82 Бетон силикатный плотный. Технические условия

475.ГОСТ 25246-82 Бетоны химически стойкие. Технические условия

476.ГОСТ 25485-89 Бетоны ячеистые. Технические условия

477.ГОСТ 25592-91 Смеси золошлаковые тепловых электростанций для бетонов

478.ГОСТ 25592-91 (с изм. 1 2000) Смеси золошлаковые тепловых электростанций для бетонов

479.ГОСТ 25820-83 (1989) Бетоны легкие. Технические условия

480.ГОСТ 25881-83 Бетоны химически стойкие. Методы испытаний

481.ГОСТ 26134-84 (1994) Бетоны. Ультразвуковой метод определения морозостойкости

482.ГОСТ 26633-91 Бетоны тяжелые и мелкозернистые. Технические условия

483.ГОСТ 27005-86 (с попр. 1989) Бетоны легкие и ячеистые. Правила контроля средней плотности 484.ГОСТ 27006-86 (1989) Бетоны. Правила подбора состава

485.ГОСТ 27677-88 Бетоны. Общие требования к проведению испытаний

486.ГОСТ 28013-98 Растворы строительные. Общие технические условия

487.ГОСТ 28570-90 Бетоны. Методы определения прочности по образцам, отобранным из конструкций 
488.ГОСТ 29167-91 Бетоны. Методы определения характеристик трещиностойкости (вязкости разрушения) при статическом нагружении

489.ГОСТ 30459-96 Добавки для бетонов. Методы определения эффективности

490.ГОСТ Р 51263-99 Полистиролбетон. Технические условия

491.ГОСТ 6617-76 (1994) Битумы нефтяные строительные. Технические условия

492.ГОСТ 11506-73 (1993) Битумы нефтяные. Метод определения температуры размягчения по кольцу и шару

493.ГОСТ 11507-78 (1997) Битумы нефтяные. Метод определения температуры хрупкости по Фраасу

494.ГОСТ 11955-82 (1998, с изм. 3 2000) Битумы нефтяные дорожные жидкие. Технические условия

495.ГОСТ 22245-90 (1997) Битумы нефтяные дорожные вязкие. Технические условия

496.ГОСТ 379-95 Кирпич и камни силикатные. Технические условия

497.ГОСТ 530-95 Кирпич и камни керамические. Технические условия

498.ГОСТ 4001-84 Камни стеновые из горных пород. Технические условия

499.ГОСТ 4001-84 (с изм. 1 2000) Камни стеновые из горных пород. Технические условия (в части методов испытаний заменен на ГОСТ 30629-99)

500.ГОСТ 4013-82 (попр. 1984) Камень гипсовый и гипсоангидритовый для производства вяжущих материалов. Технические условия

501.ГОСТ 6133-84 (с поправками 1987, 1990) Камни бетонные стеновые. Технические условия

502.ГОСТ 6665-91 Камни бетонные и железобетонные бортовые. Технические условия

503.ГОСТ 6666-81 (1986) Камни бортовые из горных пород. Технические условия

504.ГОСТ 7025-91 Кирпич и камни керамические и силикатные. Методы определения водопоглощения, плотности и контроля морозостойкости

505.ГОСТ 7484-78 (1987) Кирпич и камни керамические лицевые. Технические условия

506.ГОСТ 8426-75 Кирпич глиняный для дымовых труб

507.ГОСТ 23668-79 Камень брусчатый для дорожных покрытий. Технические условия

508.ГОСТ 23668-79 (с изм. 1 2000) Камень брусчатый для дорожных покрытий. Технические условия (в части методов испытаний заменен на ГОСТ 30629-99)

509.ГОСТ 24332-88 (с попр. 1990) Кирпич и камни силикатные. Ультразвуковой метод определения прочности при сжатии

510.ГОСТ 2678-94 (с попр. 1998) Материалы рулонные кровельные и гидроизоляционные. Метод испытаний

511.ГОСТ 2697-83 (1984) Пергамин кровельный. Технические условия

512.ГОСТ 7415-86 (1995) Гидроизол. Технические условия

513.ГОСТ 7415-86 (с изм.1 2000) Гидроизол. Технические условия

514.ГОСТ 10296-79 (1993, с изм.2 2000) Изол. Технические условия

515.ГОСТ 10923-93 (с поправками 1995, изм. 1 2000) Рубероид. Технические условия

516.ГОСТ 15879-70 (1991, с изм. 2 2000) Стеклорубероид. Технические условия

517.ГОСТ 10296-79 (1993) Изол. Технические условия

518.ГОСТ 10923-93 Рубероид. Технические условия

519.ГОСТ 15879-70 (1991) Стеклорубероид. Технические условия

520.ГОСТ 18956-73 Материалы рулонные кровельные. Методы испытаний на старение под воздействием искусственных климатических факторов

521.ГОСТ 20429-84 (1985) Фольгоизол. Технические условия

522.ГОСТ 20429-84 (1985, с изм. 1 1990, 2 2000) Фольгоизол. Технические условия

523.ГОСТ 30547-97 (с изм. 12000 ) Материалы рулонные кровельные и гидроизоляционные. Общие технические условия (взамен ГОСТ 4.203-79, 2551-75, 23835-79, 26627-85)

524.ГОСТ 30547-97 Материалы рулонные кровельные и гидроизоляционные. Общие технические условия (взамен ГОСТ 4.203-79, 2551-75, 23835-79, 26627-85)

525.ГОСТ 4765-73 (1993) Материалы лакокрасочные. Метод определения прочности при ударе

526.ГОСТ 6589-74 (1987) Материалы лакокрасочные. Метод определения степени перетира

527.ГОСТ 7930-73 (1993) Эмали НЦ-1125. Технические условия

528.ГОСТ 15140-78 (1995) Материалы лакокрасочные. Методы определения адгезии

529.ГОСТ 18958-73 (с попр. 1975) Краски силикатные

530.ГОСТ 19279-73 (1988) Краски полимерцементные 
531.ГОСТ 24404-80 (1991) Изделия из древесины и древесных материалов. Покрытия лакокрасочные. Классификация и обозначения

532.ГОСТ 7251-77 (с изм. 1 1999) Линолеум поливинилхлоридный на тканой и нетканой подоснове. Технические условия

533.ГОСТ 11529-86 (с изм. 1 1999) Материалы поливинилхлоридные для полов. Методы контроля

534.ГОСТ 16914-71 Линолеум резиновый многослойный - релин

535.ГОСТ 17241-71 (1992) Материалы и изделия полимерные для покрытия полов. Классификация

536.ГОСТ 18108-80 (1988, с изм. 1 1999) Линолеум поливинилхлоридный на теплозвукоизолирующей подоснове. Технические условия

537.ГОСТ 24210-80 Материалы полимерные рулонные и плиточные для полов. Метод определения звукоизолирующих свойств

538.ГОСТ 25609-83 Материалы полимерные рулонные и плиточные для полов. Метод определения показателя теплоусвоения

539.ГОСТ 26149-84 (1994, с изм. 1 1999) Покрытие для полов рулонное на основе химических волокон. Технические условия

540.ГОСТ 26150-84 Материалы и изделия строительные полимерные отделочные на основе поливинилхлорида. Метод санитарно-химической оценки

541.ГОСТ 26604-85 (с попр. 1987, 1989, с изм. 1 2000) Полотна нетканые (подоснова) антисептические из волокон всех видов для теплозвукоизоляционного линолеума. Технические условия

542.ГОСТ 26150-84 (с изм. 1 2000) Материалы и изделия строительные полимерные отделочные на основе поливинилхлорида. Метод санитарно-химической оценки

543.ГОСТ 26604-85 (с попр. 1987, 1989, изм. 1 2000) Полотна нетканые (подоснова) антисептические из волокон всех видов для теплозвукоизоляционного линолеума. Технические условия

544.ГОСТ 27019-86 Материалы полимерные рулонные для полов. Ускоренный метод определения звукоизоляционных свойств

545.ГОСТ 27023-86 (с изм. 1 1999) Ковры сварные из поливинилхлоридного линолеума на теплоизолирующей подоснове. Технические условия

546.ГОСТ 30548-97 Полотна нетканые (подоснова) для линолеума. Методы испытаний

547.ГОСТ 2889-80 Мастика битумная кровельная горячая. Технические условия

548.ГОСТ 14791-79 (1990) Мастика герметизирующая нетвердеющая строительная. Технические условия

549.ГОСТ 15836-79 (1995) Мастика битумно-резиновая изоляционная. Технические условия

550.ГОСТ 24064-80 (1988) Мастики клеящие каучуковые. Технические условия

551.ГОСТ 25591-83 Мастики кровельные и гидроизоляционные. Классификация и общие технические требования

552.ГОСТ 26589-94 (с попр. 1998) Мастики кровельные и гидроизоляционные. Методы испытаний

553.ГОСТ 30307-95 Мастики строительные полимерные клеящие латексные. Технические условия

554.ГОСТ 6141-91 (СТ СЭВ 2047-88) Плитки керамические глазурованные для внутренней облицовки стен. Технические условия

555.ГОСТ 6787-90 Плитки керамические для полов. Технические условия

556.ГОСТ 13996-93 (с попр. 1995, 1997) Плитки керамические фасадные и ковры из них. Технические условия

557.ГОСТ 17057-89 (с попр. 1990) Плитки стеклянные облицовочные коврово-мозаичные и ковры из них. Технические условия

558.ГОСТ 27180-86 (СТ СЭВ 4870-84) Плитки керамические. Методы испытаний

559.СТ СЭВ 3979-83 Плитки керамические. Термины и определения

560.ГОСТ 16976-71 (1983, с изм. 1 1978, 2 1982, 3 1987) Покрытия лакокрасочные. Метод определения степени меления

561.ГОСТ 23790-79 (1985) Покрытие по древесине фосфатное огнезащитное. Технические требования

562.ГОСТ 23791-79 (1985) Покрытие по стали фосфатное огнезащитное. Технические требования

563.ГОСТ 25130-82 (1987) Покрытие по древесине вспучивающееся огнезащитное ВПД. Технические требования

564.ГОСТ 25131-82 (1994) Покрытие по стали вспучивающееся огнезащитное ВПМ-2. Технические требования

565.ГОСТ 25665-83 Покрытие по стали фосфатное огнезащитное на основе минеральных волокон. Технические требования

566.ГОСТ 111-90 Стекло листовое. Технические условия 
567.ГОСТ 5533-86 (1993) Стекло листовое узорчатое. Технические условия

568.ГОСТ 7481-78 (с попр. 1989) Стекло армированное листовое. Технические условия

569.ГОСТ 17716-91 Зеркала. Общие технические условия

570.ГОСТ 21992-83 Стекло строительное профильное. Технические условия

571.ГОСТ 26302-93 Стекло. Методы определения коэффициентов направленного пропускания и отражения света

572.ГОСТ Р 51136-98 (с изм. 1 1998) Стекла защитные многослойные. Общие технические условия

573.ГОСТ 2694-78 Изделия пенодиамитовые и диамитовые теплоизоляционные. Технические условия

574.ГОСТ 4640-93 (с изм. 1 1997) Вата минеральная. Технические условия

575.ГОСТ 16381-77 (СТ СЭВ 5069-85) (1992) Материалы и изделия строительные теплоизоляционные. Классификация и общие технические требования

576.ГОСТ 17177-94 Материалы и изделия строительные теплоизоляционные. Методы испытаний

577.ГОСТ 23208-83 Цилиндры и полуцилиндры теплоизоляционные из минеральной ваты на синтетическом связующем

578.ГОСТ 24748-81 Изделия известково-кремнеземистые теплоизоляционные. Технические условия

579.ГОСТ 25880-83 Материалы и изделия строительные теплоизоляционные. Упаковка, маркировка, транспортирование и хранение

580.ГОСТ 26281-84 (1992) Материалы и изделия строительные теплоизоляционные. Правила приемки

581.ГОСТ 286-82 (1991) Трубы керамические канализационные. Технические условия

582.ГОСТ 3262-75 (1994, 1 1977, 2 1978, 3 1987, 4 1988, 5 1989, 6 1991) Трубы стальные водогазопроводные. Технические условия

583.ГОСТ 3634-89 Люки чугунные для смотровых колодцев. Технические условия

584.ГОСТ 6942-98 Трубы чугунные канализационные и фасонные части к ним. Технические условия (взамен ГОСТ 6942.0-80 - 6942.24-80, ГОСТ 4.227-83)

585.ГОСТ 8411-74 Трубы керамические дренажные. Технические условия

586.ГОСТ 8894-86 Трубы стеклянные и фасонные части к ним. Технические условия

587.ГОСТ 10704-91 (1996) Трубы стальные электросварные прямошовные. Сортамент

588.ГОСТ 10705-80 (1993, с изм. 5 1999) Трубы стальные электросварные. Технические условия

589.ГОСТ 10706-76 (1993, с изм. 4 1999) Трубы стальные электросварные прямошовные. Технические требования

590.ГОСТ 10707-80 (1995) Трубы стальные электросварные холоднодеформированные. Технические условия

591.ГОСТ 13663-86 (1994, с изм.1 1987, 2 1989) Трубы стальные профильные. Технические условия

592.ГОСТ 22130-86 Детали стальных трубопроводов. Опоры подвижные и подвески. Технические условия

593.ГОСТ 22689.0-89 (попр. 1990) Трубы полиэтиленовые канализационные и фасонные части к ним

594.ГОСТ 22689.1-89 (попр. 1990) Трубы полиэтиленовые канализационные и фасонные части к ним. Сортамент

595.ГОСТ 22689.2-89 (попр. 1990) Трубы полиэтиленовые канализационные и фасонные части к ним. Конструкция

596.ГОСТ 24950-81 Отводы гнутые и вставки кривые на поворотах линейной части стальных магистральных трубопроводов. Технические условия

597.ГОСТ 25812-83 (с попр. 1984, изм. 1,2 1987) Трубопроводы стальные магистральные. Общие требования к защите от коррозии

598.ГОСТ 26008-83 Дождеприемники чугунные для колодцев. Технические условия

599.ГОСТ 28548-90 (СТ СЭВ 6584-89) Группа В00 Трубы стальные. Термины и определения.

600.ГОСТ 8645-68 Трубы стальные прямоугольные. Сортамент.

601.ГОСТ 8696-74 Группа В62 Трубы стальные электросварные со спиральным швом общего назначения. Технические условия.

602.ГОСТ 8731-74 (СТ СЭВ 1482-78) Группа В62 Трубы стальные бесшовные горячедеформированные. Технические требования.

603.ГОСТ 8732-78 (СТ СЭВ 1481-78) Трубы стальные бесшовные горячедеформированные. Сортамент.

604.ГОСТ 8733-74 Группа В62 Трубы стальные бесшовные холоднодеформированные и теплодеформированные. Технические требования.

605.ГОСТ 8634-57 Трубы стальные двухканальные. Сортамент. 
606.ГОСТ 8635-57 Трубы стальные D-образные. Сортамент.

607.ГОСТ 8636-57 Трубы стальные желобчатые. Сортамент.

608.ГОСТ 8638-57 Трубы стальные каплевидные. Сортамент.

609.ГОСТ 8639-68 Трубы стальные каплевидные. Сортамент.

610.ГОСТ 8640-57 Трубы стальные крестообразные. Сортамент.

611.ГОСТ 8641-57 Трубы стальные круглые с шестигранным отверстием. Сортамент.

612.ГОСТ 8652-57 Трубы стальные шестигранные гаечные. Сортамент.

613.ГОСТ 13664-68 Трубы стальные звездообразные. Сортамент.

614.ГОСТ 8651-57 Трубы стальные шестигранные. Сортамент.

615.ГОСТ 8633-57 Трубы стальные восьмигранные с круглым отверстием. Сортамент.

616.ГОСТ 8632-57 Трубы стальные восьмигранные. Сортамент.

617.ГОСТ Р 51613-2000 Трубы напорные из непластифицированного поливинилхлорида. Технические условия

618.ГОСТ 310.1-76 (1992) Цементы. Методы испытаний. Общие положения

619.ГОСТ 310.2-76 (1992) Цементы. Методы определения тонкости помола

620.ГОСТ 310.3-76 (1992) Цементы. Методы определения нормальной густоты, сроков схватывания и равномерности изменения объема

621.ГОСТ 310.4-81 (1992) Цементы. Методы определения предела прочности при изгибе и сжатии

622.ГОСТ 310.5-88 (1992) Цементы. Метод определения тепловыделения

623.ГОСТ 310.6-85 (1992) Цементы. Метод определения водоотделения

624.ГОСТ 965-89 Портландцементы белые. Технические условия

625.ГОСТ 969-91 (СТ СЭВ 6826-89) Цементы глиноземистые и высокоглиноземистые. Технические условия

626.ГОСТ 1581-96 Портландцементы тампонажные. Технические условия

627.ГОСТ 3476-74 Шлаки доменные и электротермофосфорные гранулированные для производства цементов

628.ГОСТ 5382-91 Цементы и материалы цементного производства. Методы химического анализа

629.ГОСТ 6139-91 (СТ СЭВ 6951-89) Песок стандартный для испытаний цемента. Технические условия

630.ГОСТ 10178-85 (1989, с изм. 2 1999) Портландцемент и шлакопортландцемент. Технические условия

631.ГОСТ 11052-74 Цемент гипсоглиноземистый расширяющийся

632.ГОСТ 15825-80 Портландцемент цветной. Технические условия

633.ГОСТ 22266-94 Цементы сульфатостойкие. Технические условия

634.ГОСТ 24640-91 Добавки для цементов. Технические условия

635.ГОСТ 25094-94 Добавки активные минеральные для цементов. Метод испытаний

636.ГОСТ 25328-82 Цемент для строительных растворов. Технические условия

637.ГОСТ 26798.1-96 Цементы тампонажные. Методы испытаний

638.ГОСТ 26798.2-96 Цементы тампонажные типов I-G и I-H. Методы испытаний

639.ГОСТ 30515-97 Цементы. Общие технические условия (взамен СТ СЭВ 3477-81, СТ СЭВ 477284, ГОСТ 4.214-80, ГОСТ 22236-85, ГОСТ 22237-85, ГОСТ 23464-79)

640.ГОСТ 30744-2001 Цементы. Методы испытаний с использованием полифракционного песка

641.ГОСТ 3344-83 (1986) Щебень и песок шлаковые для дорожного строительства. Технические условия

642.ГОСТ 3344-83 (1986, с изм. 1 2000)) Щебень и песок шлаковые для дорожного строительства. Технические условия

643.ГОСТ 5578-94 (с попр. 1996) Щебень и песок из шлаков черной и цветной металлургии для бетонов. Технические условия

644.ГОСТ 7392-85 Щебень из природного камня для балластного слоя железнодорожного пути. Технические условия

645.ГОСТ 7394-85 (1987) Балласт гравийный и гравийно-песчаный для железнодорожного пути. Технические условия

646.ГОСТ 7392-85 (с изм. 1 2000) Щебень из природного камня для балластного слоя железнодорожного пути. Технические условия

647.ГОСТ 7394-85 (1987, с изм. 1 2000)) Балласт гравийный и гравийно-песчаный для железнодорожного пути. Технические условия 
648.ГОСТ 8267-93 (1996, с изм.1 1998, 2 2000)) Щебень и гравий из плотных горных пород для строительных работ. Технические условия

649.ГОСТ 8269.0-97 (с попр. 1999, изм. 1 2000)) Щебень и гравий из плотных горных пород и отходов строительного производства для строительных работ. Методы физико-механических испытаний

650.ГОСТ 8267-93 (1996, с изм. 1 1998) Щебень и гравий из плотных горных пород для строительных работ. Технические условия

651.ГОСТ 8269.0-97 (с попр. 1999) Щебень и гравий из плотных горных пород и отходов строительного производства для строительных работ. Методы физико-механических испытаний

652.ГОСТ 8269.1-97 Щебень и гравий из плотных горных пород и отходов строительного производства для строительных работ. Методы химического анализа

653.ГОСТ 8735-88 (1997) Песок для строительных работ. Методы испытаний

654.ГОСТ 8735-88 (1997, с изм. 1 2000)) Песок для строительных работ. Методы испытаний

655.ГОСТ 8736-93 (с изм. 1 1998, с изм. 2 2000) Песок для строительных работ. Технические условия

656.ГОСТ 9757-90 (с изм. 1 2000) Гравий, щебень и песок искусственные пористые. Технические условия

657.ГОСТ 10832-91 (с изм. 12000 ) Песок и щебень перлитовые вспученные. Технические условия

658.ГОСТ 8736-93 (с изм. 1 1998) Песок для строительных работ. Технические условия

659.ГОСТ 9757-90 Гравий, щебень и песок искусственные пористые. Технические условия

660.ГОСТ 10832-91 Песок и щебень перлитовые вспученные. Технические условия

661.ГОСТ 18866-93 Щебень из доменного шлака для производства минеральной ваты. Технические условия

662.ГОСТ 22263-76 Щебень и песок из пористых горных пород. Технические условия

663.ГОСТ 22856-89 Щебень и песок декоративные из природного камня. Технические условия

664.ГОСТ 22263-76 (с изм. 1 2000) Щебень и песок из пористых горных пород. Технические условия

665.ГОСТ 22856-89 (с изм. 1 2000) Щебень и песок декоративные из природного камня. Технические условия

666.ГОСТ 23558-94 (с изм. 1 1998, с изм. 2 2000) Смеси щебеночно-гравийно-песочные и грунты, обработанные неорганическими вяжущими материалами, для дорожного и аэродромного строительства

667.ГОСТ 23735-79 (с изм. 1 2000) Смеси песчано-гравийные для строительных работ. Технические условия

668.ГОСТ 23558-94 (с изм. 1 1998) Смеси щебеночно-гравийно-песочные и грунты, обработанные неорганическими вяжущими материалами, для дорожного и аэродромного строительства

669.ГОСТ 23735-79 Смеси песчано-гравийные для строительных работ. Технические условия

670.ГОСТ 125-79 (с попр. 1984) Вяжущие гипсовые. Технические условия

671.ГОСТ 5724-75 (1987) Линкруст

672.ГОСТ 6266-97 Листы гипсокартонные. Технические условия

673.ГОСТ 7076-99 Материалы и изделия строительные. Метод определения теплопроводности и термического сопротивления при стационарном тепловом режиме

674.ГОСТ 8462-85 Материалы стеновые. Методы определения пределов прочности при сжатии и изгибе

675.ГОСТ 9179-77 (1989) Известь строительная. Технические условия

676.ГОСТ 9479-84 (1994) Блоки из природного камня для производства облицовочных изделий. Технические условия

677.ГОСТ 9479-98 Блоки из горных пород для производства облицовочных, архитектурностроительных, мемориальных и других изделий. Технические условия

678.ГОСТ 9590-76 (1991) Пластик бумажнослоистый декоративный. Технические условия

679.ГОСТ 9758-86 (с изм. 1 1988, изм. 2 1989) Заполнители пористые неорганические для строительных работ. Методы испытаний

680.ГОСТ 10174-90 (1991) Прокладки уплотняющие пенополиуретановые для окон и дверей. Технические условия

681.ГОСТ 11583-74 (1988) Материалы полимерные строительные отделочные. Методы определения цветоустойчивости под воздействием света, равномерности окраски и светлоты

682.ГОСТ 11830-66 (1989) Строительные материалы. Норма точности взвешивания

683.ГОСТ 12784-78 Порошок минеральный для асфальтобетонных смесей. Методы испытаний

684.ГОСТ 12801-98 Материалы на основе органических вяжущих для дорожного и аэродромного строительства. Методы испытаний 
685.ГОСТ 12865-67 (1988) Вермикулит вспученный

686.ГОСТ 16297-80 Материалы звукоизоляционные и звукопоглощающие. Методы испытаний 687.ГОСТ 16557-78 Порошок минеральный для асфальтобетонных смесей. Технические условия 688.ГОСТ 18124-95 Листы асбестоцементные плоские. Технические условия

689.ГОСТ 18659-81 Эмульсии дорожные. Технические условия

690.ГОСТ 19177-81 (1995) Прокладки резиновые пористые уплотняющие. Технические условия 691.ГОСТ 19222-84 Арболит и изделия из него. Общие технические условия

692.ГОСТ 21718-84 Материалы строительные. Диэлькометрический метод измерения влажности 693.ГОСТ 22688-77 Известь строительная. Методы испытаний

694.ГОСТ 23233-78 Заполнитель сотовый бумажный. Технические условия

695.ГОСТ 23250-78 Материалы строительные. Метод определения удельной теплоемкости

696.ГОСТ 23422-87 Материалы строительные. Нейтронный метод измерения влажности

697.ГОСТ 23499-79 (1980) Материалы и изделия строительные звукопоглощающие и звукоизоляционные. Классификация и общие технические требования

698.ГОСТ 23789-79 (СТ СЭВ 826-77 в части методов испытаний) (1986) Вяжущие гипсовые. Методы испытаний

699.ГОСТ 24454-80 (1990) Пиломатериалы хвойных пород. Размеры.

700.ГОСТ 24816-81 (1988) Материалы строительные. Метод определения сорбционной влажности

701.ГОСТ 24944-81 (1993, с изм.1 2000) Пленка поливинилхлоридная декоративная отделочная. Технические условия

702.ГОСТ 25621-83 Материалы и изделия полимерные строительные герметизирующие и уплотняющие. Классификация и общие технические требования

703.ГОСТ 25818-91 Золы-уноса тепловых станций для бетонов. Технические условия

704.ГОСТ 25818-91 (с изм. 1 2000) Золы-уноса тепловых станций для бетонов. Технические условия

705.ГОСТ 25898-83 (1988) Материалы и изделия строительные. Методы определения сопротивления паропроницанию

706.ГОСТ 25945-87 (с попр. 1991) Материалы и изделия полимерные строительные герметизирующие нетвердеющие. Методы испытаний

707.ГОСТ 26417-85 Материалы звукопоглощающие строительные. Метод испытаний в малой реверберационной камере

708.ГОСТ 26871-86 Материалы вяжущие гипсовые. Правила приемки. Упаковка, маркировка, транспортирование и хранение

709.ГОСТ 27475-87 Составы влагозащитные и влагозащитно-антисептические для защиты торцов лесоматериалов. Метод определения влагозащитных свойств

710.ГОСТ 30108-94 (с изм. 1 1998) Материалы и изделия строительные. Определение удельной эффективной активности естественных радионуклидов

711.ГОСТ 30244-94 Материалы строительные. Методы испытаний на горючесть

712.ГОСТ 30256-94 Материалы и изделия строительные. Метод определения теплопроводности цилиндрическим зондом

713.ГОСТ 30290-94 Материалы и изделия строительные. Метод определения теплопроводности поверхностным преобразователем

714.ГОСТ 30340-95 (с попр. 1997) Листы асбестоцементные волнистые. Технические условия

715.ГОСТ 30402-96 Материалы строительные. Метод испытания на воспламеняемость

716.ГОСТ 30491-97 Смеси органоминеральные и грунты, укрепленные органическими вяжущими, для дорожного и аэродромного строительства. Технические условия

717.ГОСТ 30491-97 (с изм. 1 2000) Смеси органоминеральные и грунты, укрепленные органическими вяжущими, для дорожного и аэродромного строительства. Технические условия

718.ГОСТ Р 51032-97 (ГОСТ 30444-97) Материалы строительные. Метод испытания на распространение пламени

719.ГОСТ 30629-99 Материалы и изделия облицовочные из горных пород. Методы испытаний (в части методов испытаний горных пород - взамен ГОСТ 4001-84, ГОСТ 6666-81, ГОСТ 9480-89, ГОСТ 23342-91, ГОСТ 23668-79, в части определения коэффициента камненасыщения и предела прочности на растяжение при изгибе - взамен ГОСТ 24099-80)

720.ГОСТ Р 51032-97 (ГОСТ 30444-97) Материалы строительные. Метод испытания на распространение пламени

721.ГОСТ 82-70 (1988, с изм. 1 1978, 2 1982, 3 1986, 4 1987) Прокат стальной горячекатаный широкополосный универсальный. Сортамент 
722.ГОСТ 103-76 (1987) Полоса стальная горячекатаная. Сортамент

723.ГОСТ 380-94 Сталь углеродистая обыкновенного качества. Марки

724.ГОСТ 6009-74 (1986, с изм. 1 1985) Лента стальная горячекатаная. Технические условия

725.ГОСТ 8239-89 Двутавры стальные горячекатанные. Сортамент

726.ГОСТ 8283-93 Профили стальные гнутые корытные равнополочные. Сортамент

727.ГОСТ 8568-77 Листы стальные с ромбическим и чечевичным рифлением. Технические условия

728.ГОСТ 12004-81 (1995, с изм. 1 1985, 2 1990) Сталь арматурная. Методы испытания на растяжение

729.ГОСТ 14637-89 (1994) Прокат толстолистовой из углеродистой стали обыкновенного качества. Технические условия

730.ГОСТ 14918-80 (1987, с изм. 1 1981, 2 1986) Сталь тонколистовая оцинкованная с непрерывных линий. Технические условия

731.ГОСТ 24045-94 (с попр. 1996) Профили стальные листовые гнутые с трапециевидными гофрами для строительства. Технические условия

732.ГОСТ 26020-83 Двутавры стальные горячекатанные с параллельными гранями полок. Сортамент

733.ГОСТ 27772-88 (1989) Прокат для строительных стальных конструкций. Общие технические условия

734.ГОСТ 30245-94 Профили стальные гнутые замкнутые сварные квадратные и прямоугольные для строительных конструкций. Технические условия

735.ГОСТ 30246-94 Прокат тонколистовой рулонный с защитно-декоративным лакокрасочным покрытием для строительных конструкций. Технические условия

736.ГОСТ 8240-97 Швеллеры стальные горячекатанные. Сортамент.

737.ГОСТ 8281-80 (СТ СЭВ 106-74) Швеллеры стальные гнутые неравнополочные. Сортамент.

738.ГОСТ 2771-81 Проволока круглая холоднотянутая. Сортамент.

739.ГОСТ 13981-87 (с попр. 1990) Формы для изготовления железобетонных виброгидропрессованных напорных труб. Технические условия

740.ГОСТ 25781-83 (1994) Формы стальные для изготовления железобетонных изделий. Технические условия

741.ГОСТ 26438-85 Формы стальные для изготовления железобетонных изделий. Методы испытаний на деформативность

742.ГОСТ 27204-87 (с попр. 1988, 1990, с изм. 1 1991) Формы стальные для изготовления железобетонных изделий. Борта. Конструкция и размеры

743.ГОСТ 13981-87 (с попр. 1990) Формы для изготовления железобетонных виброгидропрессованных напорных труб. Технические условия

744.ГОСТ 18103-84 Установки для изготовления железобетонных объемных блоков санитарнотехнических кабин и шахт лифтов. Технические условия

745.ГОСТ 18343-80 (1991) Поддоны для кирпича и керамических камней. Технические условия

746.ГОСТ 21807-76 (1988) Бункеры (бадьи) переносные вместимостью до 2 м3 бетонной смеси. Общие технические условия

747.ГОСТ 23407-78 Ограждения инвентарные строительных площадок и участков производства строительно-монтажных работ. Технические условия

748.ГОСТ 23421-79 Устройство для пакетной перевозки силикатного кирпича автомобильным транспортом. Основные параметры и размеры

749.ГОСТ 23477-79 (1989) Опалубка разборно-переставная мелкощитовая инвентарная для возведения монолитных бетонных и железобетонных конструкций. Технические условия

750.ГОСТ 23478-79 (1993) Опалубка для возведения монолитных бетонных и железобетонных конструкций. Классификация и общие технические требования

751.ГОСТ 24259-80 Оснастка монтажная для временного закрепления и выверки конструкций зданий. Классификация и общие технические требования

752.ГОСТ 24741-81 (1993) Узел крепления крановых рельсов к стальным подкрановым балкам. Технические условия

753.ГОСТ 25032-81 Средства грузозахватные. Классификация и общие технические требования

754.ГОСТ 25646-95 Эксплуатация строительных машин. Общие требования

755.ГОСТ 25781-83 (1994) Формы стальные для изготовления железобетонных изделий. Технические условия

756.ГОСТ 26887-86 Площадки и лестницы для строительно-монтажных работ. Общие технические условия

757.ГОСТ 27321-87 Леса стоечные приставные для строительно-монтажных работ. Технические условия 
758.ГОСТ 27372-87 (1992) Люльки для строительно-монтажных работ. Технические условия 759.ГОСТ 28012-89 Подмости передвижные сборно-разборные. Технические условия

760.ГОСТ 28347-89 Подмости передвижные с перемещаемым рабочим местом. Технические условия

761.ГОСТ 28715-90 Формы стальные для изготовления железобетонных изделий. Проемообразователи и вкладыши. Конструкция

762.ГОСТ Р 50849-96 (2000) Пояса предохранительные. Общие технические условия

763.ГОСТ Р 51033-97 Показатели эксплуатационной и ремонтной технологичности строительных машин

764.ГОСТ Р 51041-97 Молоты сваебойные. Общие технические условия

765.ГОСТ Р 51248-99 (с попр. 1999) Пути наземные рельсовые крановые. Общие технические требования (взамен СНиП 3.08.01-85)

766.ГОСТ 17.0.0.01-76 (СТ СЭВ 1364-78) (с изм. 1 1979, изм. 2 1987) Система стандартов в области охраны природы и улучшения использования природных ресурсов. Основные положения

767.ГОСТ 17.0.0.02-79 (1980) Охрана природы. Метрологическое обеспечение контроля загрязненности атмосферы, поверхностных вод и почвы. Основные положения

768.ГОСТ 17.0.0.04-90 (1998) Охрана природы. Экологический паспорт промышленного предприятия. Основные положения

769.ГОСТ 17.1.3.05-82 Охрана природы. Гидросфера. Общие требования к охране поверхностных и подземных вод от загрязнения нефтью и нефтепродуктами

770.ГОСТ 17.1.3.06-82 (СТ СЭВ 3079-81) Охрана природы. Гидросфера. Общие требования к охране подземных вод

771.ГОСТ 17.1.3.10-83 (СТ СЭВ 3545-82) Охрана природы. Гидросфера. Общие требования к охране поверхностных и подземных вод от загрязнения нефтью и нефтепродуктами при транспортированию по трубопроводу

772.ГОСТ 17.1.3.12-86 Охрана природы. Гидросфера. Общие правила охраны вод от загрязнения при бурении и добыче нефти и газа на суше

773.ГОСТ 17.1.3.13-86 (СТ СЭВ 4468-84) Охрана природы. Гидросфера. Общие требования к охране поверхностных вод

774.ГОСТ 17.1.4.01-80 Охрана природы. Гидросфера. Общие требования к методам определения нефтепродуктов в природных и сточных водах

775.ГОСТ 17.2.3.02-78 Охрана природы. Атмосфера. Правила установления допустимых выбросов вредных веществ промышленными предприятиями

776.ГОСТ 17.4.3.02-85 (СТ СЭВ 4471-84) Охрана природы. Почвы. Требования к охране плодородного слоя почвы при производстве земляных работ

777.ГОСТ 17.5.1.02-85 Охрана природы. Земли. Классификация нарушенных земель для рекультивации

778.ГОСТ 17.5.3.02-90 Охрана природы. Земли. Нормы выделения на землях государственного лесного фонда защитных полос вдоль железных и автомобильных дорог

779.ГОСТ 17.5.3.03-80 Охрана природы. Земли. Общие требования к гидролесомелиорации

780.ГОСТ 17.5.3.04-83 (СТ СЭВ 5302-85) (с изм. 1 1986) Охрана природы. Земли. Общие требования к рекультивации земель

781.ГОСТ 17.5.3.06-85 Охрана природы. Земли. Требования к определению норм снятия плодородного слоя почвы при производстве земляных работ

782.ГОСТ 17.5.4.01-84 Охрана природы. Рекультивация земель. Метод определения $\mathrm{pH}$ водной вытяжки вскрышных и вмещающих пород

783.ГОСТ Р 17.2.02.06-99 Охрана природы. Атмосфера. Нормы и методы измерения содержания оксида углерода и углеводородов в отработавших газах газобалонных автомобилей

784.ГОСТ Р ИСО 14001-98 Системы управления окружающей средой. Требования и руководство по применению

785.ГОСТ Р ИСО 14004-98 Системы управления окружающей средой. Общие руководящие указания по принципам, системам и средствам обеспечения функционирования

786.ГОСТ Р ИСО 14010-98 Руководящие указания по экологическому аудиту. Основные принципы

787.ГОСТ Р ИСО 14011-98 Руководящие указания по экологическому аудиту. Процедуры аудита. Проведение аудита систем управления окружающей средой

788.ГОСТ Р ИСО 14012-98 Руководящие указания по экологическому аудиту. Квалификационные критерии для аудиторов в области экологии

789.ГОСТ Р ИСО 14020-99 Экологические этикетки и декларации. Основные принципы

790.ГОСТ Р ИСО 14040-99 Управление окружающей средой. Оценка жизненного цикла. Принципы и структура 
791.ГОСТ Р ИСО 14041-2000 Управление окружающей средой. Оценка жизненного цикла. Определение цели, области исследования и инвентаризационный анализ

792.ГОСТ Р ИСО 14050-99 Управление окружающей средой. Словарь

793.ГОСТ 27.001-95 Система стандартов "надежность в технике". Основные положения

794.ГОСТ 27.310-95 Анализ видов, последствий и критичности отказов. Основные положения

795.ГОСТ 3706-93 Задвижки. Строительные размеры

796.ГОСТ 4609-49 (1954) Оборудование сливоналивное для горючих и легковоспламеняющихся жидкостей. Стояк сливоналивной одинокий с ручным насосом

797.ГОСТ 4610-49 (1954) Оборудование сливоналивное для горючих и легковоспламеняющихся жидкостей. Стояк сливоналивной одинокий механизированный

798.ГОСТ 5264-80 (1993) Ручная дуговая сварка. Соединения сварные. Основные типы, конструктивные элементы и размеры

799.ГОСТ 7512-82 (1994) Контроль неразрушающий. Соединения сварные. Радиографический метод

800.ГОСТ 13448-82 Решетки вентиляционные пластмассовые. Технические условия

801.ГОСТ 19433-88 (1996) Грузы опасные. Классификация и маркировка

802.ГОСТ 22160-76 Купола из органического стекла двухслойные. Технические условия

803.ГОСТ 24146-89 Зрительные залы. Метод измерения времени реверберации

804.ГОСТ 24258-88 Средства подмащивания. Общие технические условия

805.ГОСТ 24379.0-80 (1991) Болты фундаментные. Общие технические условия

806.ГОСТ 24379.1-80 (1991) Болты фундаментные. Конструкция и размеры

807.ГОСТ 25346-89 (с попр. 1992) Основные нормы взаимозаменяемости. Единая система допусков и посадок. Общие положения, ряды допусков и основных отклонений

808.ГОСТ 25588-83 (СТ СЭВ 3550-82) (с изм. 1 1987) Контейнеры крупнотоннажные. Маркировка

809.ГОСТ 25902-83 Зрительные залы. Метод определения разборчивости речи

810.ГОСТ 26598-85 (1987) Контейнеры и средства пакетирования в строительстве. Общие технические условия

811.ГОСТ 26805-86 Заклепка трубчатая для односторонней клепки тонколистовых строительных металлоконструкций. Технические условия

812.ГОСТ 26966-86 Сооружения водозаборные, водосбросные и затворы. Термины и определения

813.ГОСТ 27330-87 (с изм. 1 1989) Воздухонагреватели. Типы и параметры

814.ГОСТ 28310-89 Коллекторы солнечные. Общие технические условия

815.ГОСТ 28778-90 Болты самоанкерующиеся распорные для строительства. Технические условия

816.ГОСТ 30353-95 Полы. Метод испытания на стойкость к ударным воздействиям

817.ГОСТ Р 42.0.01-2000 Гражданская оборона. Основные положения

818.ГОСТ Р 50995.3.1-96 Технологическое обеспечение создания продукции. Технологическая подготовка производства

819.ГОСТ Р 51164-98 Трубопроводы стальные магистральные. Общие требования к защите от коррозии

820.ГОСТ Р 51232-98 Вода питьевая. Общие требования к организации и методам контроля качества

821.СТ СЭВ 383-87 Пожарная безопасность в строительстве. Термины и определения

822.СТ СЭВ 446-77 Противопожарные нормы строительного проектирования. Методика определения расчетной пожарной нагрузки

823.СТ СЭВ 4420-83 Защита от коррозии в строительстве. Общие положения

824.ГОСТ 34.601-90 Автоматизированные системы. Стадии создания.

825.ГОСТ 7.32-91 (ИСО 5966-82) Отчёт о научно-исследовательской работе. Структура и правила оформления.

826.ГОСТ 25867-83 (СТ СЭВ 3650-82) Сосуды с рубашками. нормы и методы расчёта на прочность.

827.ГОСТ 7.82-2001 Библиографическая запись. Библиографическое описание электронных ресурсов. Общие требования и правила составления.

828.ГОСТ 7.83-2001 Электронные издания. Основные виды и выходные сведения.

829.ГОСТ Р 51617-2000 Жилищно-коммунальные услуги. Общие технические условия

830.ГОСТ Р 51188-98 Испытание программых средств на наличие компьютерных вирусов. Типовое руководство.

831.ГОСТ 19433-88 (с изм. 1 1996) Грузы опасные. Классификация и маркировка. 
832.ГОСТ 15.001-88 (1997) Система разработки и постановки продукции на производство. Продукция производственно-технического назначения

833.ГОСТ 15.101-98 Система разработки и постановки продукции на производство. Порядок выполнения научно-исследовательских работ

834.ГОСТ 15.309-98 Система разработки и постановки продукции на производство. Испытания и приемка выпускаемой продукции

835.ГОСТ 15.601-98 Система разработки и постановки продукции на производство. Техническое обслуживание и ремонт техники. Основные положения

836.ГОСТ 15.901-91 Система разработки и постановки продукции на производство. Конструкции, изделия и материалы строительные

837.ГОСТ Р 15.000-94 Система разработки и постановки продукции на производство. Основные положения

838.ГОСТ Р 15.011-96 Система разработки и постановки продукции на производство. Патентные исследования. Содержание и порядок проведения

839.ГОСТ 10317-79 Платы печатные. Основные размеры.

840.ГОСТ 23751-86 Платы печатные. Основные параметры конструкции.

841.ГОСТ Р 51740-2001 Технические условия на пищевые продукты. Общие требования к разработке и оформлению.

842.ГОСТ 3.1130-93 Общие требования к формам и бланкам документов

843.ГОСТ 21.001-93 СПДС. Общие положения

844.ГОСТ 21.002-81 СПДС. Нормоконтроль проектно-сметной документации

845.ГОСТ 21.101-97 СПДС. Основные требования к проектной и рабочей документации

846.ГОСТ 21.110-95 СПДС. Правила выполнения спецификации оборудования, изделий и материалов

847.ГОСТ 21.112-87 (1988) СПДС. Подъемно-транспортное оборудование. Условные обозначения

848.ГОСТ 21.113-88 (СТ СЭВ 6073-87) СПДС. Обозначения характеристик точности

849.ГОСТ 21.114-95 СПДС. Правила выполнения эскизных чертежей общих видов нетиповых изделий

850.ГОСТ 21.203-78 СПДС. Правила учета и хранения подлинников проектной документации

851.ГОСТ 21.204-93 СПДС. Условные графические обозначения и изображения элементов, генеральных планов и сооружений транспорта

852.ГОСТ 21.205-93 (1995) СПДС. Условные обозначения элементов санитарно-технических систем

853.ГОСТ 21.206-93 (1995) СПДС. Условные обозначения трубопроводов

854.ГОСТ 21.302-96 СПДС. Условные графические обозначения в документации по инженерногеологическим изысканиям

855.ГОСТ 21.401-88 СПДС. Технология производства. Основные требования к рабочим чертежам

856.ГОСТ 21.402-83 СПДС. Антикоррозийная защита технологических аппаратов, газоходов и трубопроводов. Рабочие чертежи

857.ГОСТ 21.403-80 СПДС. Обозначения условные графические в схемах. Оборудование энергетическое

858.ГОСТ 21.404-85 СПДС. Автоматизация технологических процессов. Обозначения условные приборов и средств автоматизации в схемах

859.ГОСТ 21.405-93 (1995) СПДС. Правила выполнения рабочей документации тепловой изоляции оборудования и трубопроводов

860.ГОСТ 21.406-88 (1998) СПДС. Проводные средства связи. Обозначения условные графические на схемах и планах

861.ГОСТ 21.408-93 СПДС. Правила выполнения рабочей документации автоматизации технологических процессов

862.ГОСТ 21.501-93 СПДС. Правила выполнения архитектурно-строительных рабочих чертежей

863.ГОСТ 21.507-81 СПДС. Интерьеры. Рабочие чертежи

864.ГОСТ 21.508-93 (1995) СПДС. Правила выполнения рабочей документации генеральных планов предприятий, сооружений и жилищно-гражданских объектов

865.ГОСТ 21.513-83 СПДС. Антикоррозионная защита конструкций зданий и сооружений. Рабочие чертежи

866.ГОСТ 21.601-79 (1983) СПДС. Водопровод и канализация. Рабочие чертежи

867.ГОСТ 21.602-79 (с изм. 1 1981) СПДС. Отопление, вентиляция и кондиционирование воздуха. Рабочие чертежи

868.ГОСТ 21.603-80 СПДС. Связь и сигнализация. Рабочие чертежи

869.ГОСТ 21.604-82 (1992) СПДС. Водоснабжение и канализация. Наружные сети. Рабочие чертежи 
870.ГОСТ 21.605-82 (СТ СЭВ 5676-86) (1997) СПДС. Сети тепловые (тепломеханическая часть). Рабочие чертежи

871.ГОСТ 21.606-95 СПДС. Правила выполнения рабочей документации тепломеханических решений котельных

872.ГОСТ 21.607-82 СПДС. Электрическое освещение территории промышленных предприятий. Рабочие чертежи

873.ГОСТ 21.608-84 СПДС. Внутреннее электрическое освещение. Рабочие чертежи

874.ГОСТ 21.609-83 СПДС. Газоснабжение. Внутренние устройства

875.ГОСТ 21.610-85 (1987) СПДС. Газоснабжение. Наружные газопроводы. Рабочие чертежи

876.ГОСТ 21.611-85 СПДС. Централизованное управление энергоснабжением. Условные графические и буквенные обозначения вида и содержания информации

877.ГОСТ 21.613-88 СПДС. Силовое электрооборудование. Рабочие чертежи

878.ГОСТ 21.614-88 (с попр. 1988) СПДС. Изображения условные графические электрооборудования и проводок на планах

879.ГОСТ 21.615-88 (СТ СЭВ 6071-87) СПДС. Правила выполнения чертежей гидротехнических сооружений

880.ГОСТ 21.616-88 (СТ СЭВ 6072-87) СПДС. Правила выполнения чертежей гидромелиоративных линейных сооружений

881.ГОСТ Р 21.1207-97 СПДС. Условные графические обозначения на чертежах автомобильных дорог

882.ГОСТ Р 21.1701-97 СПДС. Правила выполнения рабочей документации автомобильных дорог

883.ГОСТ Р 21.1702-96 СПДС. Правила выполнения рабочей документации железнодорожных путей

884.СТ СЭВ 1565-79 Нормативно-техническая документация в строительстве. Буквенные обозначения

885.ГОСТ Р 21.1703-2000 СПДС. Правила выполнения рабочей документации проводных средств связи.

886.ГОСТ 4.200-78 СПКП. Строительство. Основные положения

887.ГОСТ 4.201-79 СПКП. Строительство. Материалы и изделия теплоизоляционные. Номенклатура показателей

888.ГОСТ 4.202-79 (1995 с изм. 1 1983) СПКП. Строительство. Изделия асбестоцементные. Номенклатура показателей

889.ГОСТ 4.204-79 (1991) СПКП. Строительство. Материалы вяжущие: известь, гипс и вещества вяжущие на их основе. Номенклатура показателей

890.ГОСТ 4.205-79 (1995) СПКП. Строительство. Стекло строительное и изделия из стекла и шлакоситалла. Номенклатура показателей

891.ГОСТ 4.206-83 (1988) СПКП. Строительство. Материалы стеновые каменные. Номенклатура показателей

892.ГОСТ 4.207-79 (1995) СПКП. Строительство. Плиты древесноволокнистые. Номенклатура показателей

893.ГОСТ 4.208-79 СПКП. Строительство. Конструкции деревянные клееные. Номенклатура показателей

894.ГОСТ 4.209-79 СПКП. Материалы и изделия звукопоглощающие и звукоизоляционные. Номенклатура показателей

895.ГОСТ 4.210-79 СПКП. Строительство. Материалы керамические отделочные и облицовочные. Номенклатура показателей

896.ГОСТ 4.211-80 СПКП. Материалы строительные нерудные и заполнители для бетона пористые. Номенклатура показателей

897.ГОСТ 4.212-80 СПКП. Бетоны. Номенклатура показателей

898.ГОСТ 4.215-81 СПКП. Приборы для окон и дверей. Номенклатура показателей

899.ГОСТ 4.217-81 СПКП. Формы для изготовления железобетонных изделий. Номенклатура показателей

900.ГОСТ 4.219-81 СПКП. Строительство. Материалы облицовочные из природного камня и блоки для их изготовления. Номенклатура показателей

901.ГОСТ 4.220-82 СПКП. Строительство. Панели легкие ограждающие с утеплителем из пенопласта. Номенклатура показателей

902.ГОСТ 4.221-82 СПКП. Строительство. Строительные конструкции и изделия из алюминиевых сплавов. Номенклатура показателей

903.ГОСТ 4.222-83 СПКП. Мастики кровельные и гидроизоляционные. Номенклатура показателей

904.ГОСТ 4.223-83 СПКП. Строительство. Изделия паркетные. Номенклатура показателей 
905.ГОСТ 4.224-83 СПКП. Материалы и изделия полимерные строительные герметизирующие и уплотняющие. Номенклатура показателей

906.ГОСТ 4.225-83 (1983) СПКП. Строительство. Трубы керамические канализационные и дренажные. Номенклатура показателей

907.ГОСТ 4.226-83 (1992) СПКП. Окна, двери и ворота деревянные. Номенклатура показателей

908.ГОСТ 4.228-83 (1987) СПКП. Строительство. Материалы клеящие полимерные. Номенклатура показателей

909.ГОСТ 4.229-83 СПКП. Строительство. Пластики бумажно-слоистые декоративные. Номенклатура показателей

910.ГОСТ 4.230-83 (1995) СПКП. Строительство. Материалы отделочные и изделия облицовочные полимерные. Номенклатура показателей

911.ГОСТ 4.233-86 (1992) СПКП. Растворы строительные. Номенклатура показателей

912.ГОСТ 4.250-79 (с попр. 1980) СПКП. Строительство. Бетонные и железобетонные изделия и конструкции. Номенклатура показателей

913.ГОСТ 4.251-79 (1989) СПКП. Строительство. Кровли. Номенклатура показателей

914.ГОСТ 4.252-84 (1985) СПКП. Строительство. Здания мобильные (инвентарные). Номенклатура показателей

915.ГОСТ 4.253-80 СПКП. Конструкции стальные. Номенклатура показателей

916.ГОСТ 12.0.001-82 (1999) ССБТ. Основные положения

917.ГОСТ 12.0.002-80 (1999) ССБТ. Термины и определения

918.ГОСТ 12.0.003-74 (1999) ССБТ. Опасные и вредные производственные факторы классификации

919.ГОСТ 12.0.004-90 (1999) ССБТ. Организация обучения безопасности труда. Общие положения

920.ГОСТ 12.0.005-84 (1999) ССБТ. Метрологическое обеспечение в области безопасности труда. Основные положения

921.ГОСТ 12.1.001-89 (1999) ССБТ. Ультразвук. Общие требования безопасности

922.ГОСТ 12.1.002-84 (1999) ССБТ. Электрические поля промышленной частоты. Допустимые уровни напряженности и требования к проведению контроля на рабочих местах

923.ГОСТ 12.1.003-83 (1991) ССБТ. Шум. Общие требования безопасности

924.ГОСТ 12.1.004-91 (1999) ССБТ. Пожарная безопасность. Общие требования

925.ГОСТ 12.1.005-88 (1991) ССБТ. Общие санитарно-гигиенические требования к воздуху санитарной зоны

926.ГОСТ 12.1.006-84 (1999) ССБТ. Электромагнитные поля радиочастот. Допустимые уровни на рабочих местах и требования к проведению контроля

927.ГОСТ 12.1.007-76 (1999) ССБТ. Вредные вещества. Классификация и общие требования безопасности

928.ГОСТ 12.1.008-76 (1999) ССБТ. Биологическая безопасность. Общие требования

929.ГОСТ 12.1.009-76 (1999) ССБТ. Электробезопасность. Термины и определения

930.ГОСТ 12.1.010-76 (1999) ССБТ. Взрывобезопасность. Общие требования

931.ГОСТ 12.1.011-78 (СТ СЭВ 2775-80) (1991) ССБТ. Смеси взрывоопасные. Классификация и методы испытаний

932.ГОСТ 12.1.012-90 (1996) ССБТ. Вибрационная безопасность. Общие требования

933.ГОСТ 12.1.014-84 (1996) ССБТ. Воздух рабочей зоны. Метод измерения концентраций вредных веществ индикаторными трубками

934.ГОСТ 12.1.016-79 (1996) ССБТ. Воздух рабочей зоны. Требования к методикам измерения концентраций вредных веществ

935.ГОСТ 12.1.018-93 (1996) ССБТ. Пожаровзрывобезопасность статического электричества. Общие требования

936.ГОСТ 12.1.019-79 (1996) ССБТ. Электробезопасность. Общие требования и номенклатура видов заг

937.ГОСТ 12.1.020-79 (1996) ССБТ. Шум. Метод контроля на морских и речных судах

938.ГОСТ 12.1.023-80 (1996) ССБТ. Шум. Методы установления значений шумовых характеристик стационарных машин

939.ГОСТ 12.1.024-81 (СТ СЭВ 3076-81) (1996) ССБТ. Шум. Определение шумовых характеристик источников шума в заглушенной камере. Точный метод

940.ГОСТ 12.1.025-81 (СТ СЭВ 3080-81) (1996) ССБТ. Шум. Определение шумовых характеристик источников шума в реверберационной камере. Точный метод

941.ГОСТ 12.1.026-80 (1996) ССБТ. Шум. Определение шумовых характеристик источников шума в свободном звуковом поле над звукоотражающей плоскостью. Технический метод 
942.ГОСТ 12.1.027-80 (СТ СЭВ 1414-78) (1996) ССБТ. Шум. Определение шумовых характеристик источников шума в реверберационном помещении. Технический метод

943.ГОСТ 12.1.030-81 (1996) ССБТ. Электробезопасность. Защитное заземление. Зануление

944.ГОСТ 12.1.033-81 (с изм. 1 1983) ССБТ. Пожарная безопасность. Термины и определения

945.ГОСТ 12.1.036-81 (1996) ССБТ. Шум. Допустимые уровни в жилых и общественных зданиях

946.ГОСТ 12.1.038-82 (1996) ССБТ. Электробезопасность. Предельно допустимые значения напряжений прикосновения и токов

947.ГОСТ 12.1.040-83 (1996) ССБТ. Лазерная безопасность. Общие положения

948.ГОСТ 12.1.041-83 (с изм. 1 1989, 2 1991) ССБТ. Пожаровзрывобезопасность горючих пылей. Общие требования

949.ГОСТ 12.1.044-89 ССБТ. Пожаровзрывоопасность веществ и материалов. Номенклатура показателей и методы их определения

950.ГОСТ 12.1.045-84 (1988) ССБТ. Электростатические поля. Допустимые уровни на рабочих местах и требования к проведению контроля

951.ГОСТ 12.1.046-85 ССБТ. Строительство. Нормы освещения строительных площадок

952.ГОСТ 12.1.047-85 (1988) ССБТ. Вибрация. Метод контроля на рабочих местах и в жилых помещениях морских и речных судов

953.ГОСТ 12.1.048-85 (1988) ССБТ. Контроль радиационный при захоронении радиоактивных отходов. Номенклатура контролируемых параметров

954.ГОСТ 12.1.114-82 ССБТ. Пожарные машины и оборудование. Обозначения условные графические

955.ГОСТ 12.2.003-91 ССБТ. Оборудование производственное. Общие требования безопасности

956.ГОСТ 12.2.007.2-75 (1985) ССБТ. Трансформаторы силовые и реакторы электрические. Требования безопасности

957.ГОСТ 12.2.007.9-93 (МЭК 510-1-84) ССБТ. Безопасность электротермического оборудования. Часть 1. Общие требования

958.ГОСТ 12.2.007.10-87 ССБТ. Установки, генераторы и нагреватели индукционные для электротермии, установки и генераторы ультразвуковые. Требования безопасности

959.ГОСТ 12.2.007.12-88 ССБТ. Источники тока химические. Требования безопасности

960.ГОСТ 12.2.007.13-88 (1989) ССБТ. Лампы электрические. Требования безопасности

961.ГОСТ 12.2.020-76 (1996) ССБТ. Электрооборудование взрывозащищенное. Термины и определения. Классификация. Маркировка

962.ГОСТ 12.2.021-76 (1996) ССБТ. Электрооборудование взрывозащищенное. Порядок согласования технической документации, проведения испытаний, выдачи заключений и свидетельств

963.ГОСТ 12.2.022-80 (1996) ССБТ. Конвейеры. Общие требования безопасности

964.ГОСТ 12.2.028-84 (с изм. 1 1989, с изм. 2 1990) ССБТ. Вентиляторы общего назначения. Методы определения шумовых характеристик

965.ГОСТ 12.2.037-78 (1996) ССБТ. Техника пожарная. Требования безопасности

966.ГОСТ 12.2.044-80 (1986, с изм. 2 1990) ССБТ. Машины и оборудование для транспортирования нефти. Требования безопасности

967.ГОСТ 12.2.047-86 (СТ СЭВ 5226-85) ССБТ. Пожарная техника. Термины и определения

968.ГОСТ 12.2.052-81 (1988) ССБТ. Оборудование, работающее с газообразным кислородом. Общие требования безопасности

969.ГОСТ 12.2.061-81 (СТ СЭВ 2695-80) ССБТ. Оборудование производственное. Общие требования безопасности к рабочим местам

970.ГОСТ 12.2.062-81 (1985) ССБТ. Оборудование производственное. Ограждения защитные

971.ГОСТ 12.2.063-81 (с изм. 1 1987) ССБТ. Арматура промышленная трубопроводная. Общие требования безопасности

972.ГОСТ 12.2.085-82 (СТ СЭВ 3085-81) (1985) ССБТ. Сосуды, работающие под давлением. Клапаны предохранительные. Требования безопасности

973.ГОСТ 12.2.092-94 ССБТ. Оборудование электромеханическое и электронагревательное для предприятий общественного питания. Общие технические требования по безопасности и методы испытаний

974.ГОСТ 12.3.001-85 (СТ СЭВ 3274-81) (1996) ССБТ. Пневмоприводы. Общие требования безопасности к монтажу, испытаниям и эксплуатации

975.ГОСТ 12.3.009-76 (СТ СЭВ 3518-81) (1996) ССБТ. Работы погрузочно-разгрузочные. Общие требования безопасности

976.ГОСТ 12.3.016-87 (1996) ССБТ. Работа антикоррозионные. Требования безопасности

977.ГОСТ 12.3.018-79 ССБТ. Системы вентиляционные. Методы аэродинамических испытаний 
978.ГОСТ 12.3.020-80 (1999) ССБТ. Процессы перемещения грузов на предприятиях. Общие требования безопасности

979.ГОСТ 12.3.033-84 ССБТ. Строительные машины. Общие требования безопасности при эксплуатации

980.ГОСТ 12.3.035-84 (1996) ССБТ. Работы окрасочные. Требования безопасности

981.ГОСТ 12.3.038-85 ССБТ. Строительство. Работы по тепловой изоляции оборудования и трубопроводов. Требования безопасности

982.ГОСТ 12.3.040-86 ССБТ. Строительство. Работы кровельные и гидроизоляционные. Требования безопасности

983.ГОСТ 12.3.046-91 ССБТ. Установки пожаротушения автоматические. Общие технические требования

984.ГОСТ 12.4.002-97 ССБТ. Средства защиты рук от вибрации. Технические требования и методы испытаний

985.ГОСТ 12.4.009-83 (1996) ССБТ. Пожарная техника для защиты объектов. Основные виды. Размещение и обслуживание

986.ГОСТ 12.4.010-75 (1996) ССБТ. Средства индивидуальной защиты. Рукавицы специальные. Технические условия

987.ГОСТ 12.4.011-89 (СТ СЭВ 1086-88) ССБТ. Средства защиты работающих. Общие требования и классификация

988.ГОСТ 12.4.012-83 (1986) ССБТ. Вибрация. Средства измерения и контроля вибрации на рабочих местах. Технические требования

989.ГОСТ 12.4.016-83 (1996) ССБТ. Одежда специальная защитная. Номенклатура показателей качества

990.ГОСТ 12.4.021-75 (1999) ССБТ. Системы вентиляционные. Общие требования

991.ГОСТ 12.4.026-76 (1987) ССБТ. Цвета сигнальные и знаки безопасности (взамен ГОСТ 15548-70)

992.ГОСТ 12.4.041-89 (СТ СЭВ 4565-84) (1997) ССБТ. Средства индивидуальной защиты органов дыхания фильтрующие. Общие технические требования (взамен ГОСТ 12.4.041-78, ГОСТ 12.4.042-78)

993.ГОСТ 12.4.059-89 ССБТ. Строительство. Ограждения предохранительные инвентарные. Общие технические условия

994.ГОСТ 12.4.087-84 (1991) ССБТ. Каски строительные. Технические условия

995.ГОСТ 12.4.099-80 (199) ССБТ. Комбинезоны женские для защиты от нетоксичной пыли, механических воздействий и общих производственных загрязнений. Технические условия

996.ГОСТ 12.4.100-80 (199) ССБТ. Комбинезоны мужские для защиты от нетоксичной пыли, механических воздействий и общих производственных загрязнений. Технические условия

997.ГОСТ 12.4.107-82 (1987) ССБТ. Строительство. Канаты страховочные. Общие технические требования

998.ГОСТ 12.4.111-82 (1987) ССБТ. Костюмы мужские для защиты от нефти и нефтепродуктов. Технические условия

999.ГОСТ 12.4.119-82 ССБТ. Средства индивидуальной защиты органов дыхания. Метод оценки защитных свойств по аэрозолям

1000. ГОСТ 12.4.120-83 (1988) ССБТ. Средства коллективной защиты от ионизирующих излучений. Общие технические требования

1001. ГОСТ 12.4.125-83 (1985) ССБТ. Средства коллективной защиты работающих от воздействия механических факторов. Классификация

1002. ГОСТ 12.4.127-83 (СТ СЭВ 3402-81) (1989) ССБТ. Обувь специальная. Номенклатура показателей качества (взамен ГОСТ 12.4.018-76, ГОСТ 12.4.071-79)

1003. ГОСТ 12.4.155-85 ССБТ. Устройства защитного отключения. Классификация. Общие технические требования

1004. ГОСТ Р 12.1.052-97 (с изм.1 1999) ССБТ. Информация о безопасности веществ и материалов (паспорт безопасности). Основные положения (взамен ГОСТ Р 50587-93)

1005. ГОСТ Р 12.2.142-99 ССБТ. Системы холодильные холодопроизводительностью свыше 3.0 кВт. Требования безопасности

1006. ГОСТ Р 12.3.047-98 ССБТ. Пожарная безопасность технологических процессов. Общие требования. Методы контроля

1007. ГОСТ Р 12.4.186-97 ССБТ. Аппараты дыхательные воздушные изолирующие. Общие технические условия и методы испытаний

1008. ГОСТ Р 12.0.006-2002 Общие требования к управлению охраной труда в организации.

1009. ГОСТ 12.1.004-91 ССБТ. Пожарная безопасность. Общие требования

1010. ГОСТ 12.1.007-76 (1996) ССБТ. Вредные вещества. Классификация и общие требования безопасности. 
1011. ГОСТ 12.1.011-78 (СТ СЭВ 2775-80) (1982) ССБТ. Смеси взрывоопасные. Классификация и методы испытаний.

1012. ГОСТ 12.1.018-93 ССБТ. Пожаровзрывобезопасность статического электричества. Общие требования

1013. ГОСТ 12.1.019-79 ССБТ. Электробезопасность. Общие требования.

1014. ГОСТ 12.1.033-81 ССБТ. Пожарная безопасность. Термины и определения.

1015. ГОСТ 12.1.044-89 ССБТ. Пожаровзрывоопасность веществ и материалов. Номенклатура показателей и методы их определения.(Ещё один вариант).

1016. ГОСТ 12.1.041-83 ССБТ. Пожаровзрывобезопасность горючих пылей. Общие требования.

1017. ГОСТ 12.4.026-76 (с изм. 1,2 1987) ССБТ. Цвета сигнальные и знаки безопасности (взамен ГОСТ 15548-70).

1018. ГОСТ 12.1.010-76 (1996) ССБТ. Взрывобезопасность. Общие требования.

1019. ГОСТ 26342-84 Средства охранной, пожарной и охранно-пожарной сигнализации. Типы, основные параметры и размеры.

1020. ГОСТ 27331-87 (СТ СЭВ 5637-86) Пожарная техника. Классификация пожаров.

1021. ГОСТ Р 12.0.006-2002 Общие требования к управлению охраной труда в организации.(Ещё один вариант)

1022. ГОСТ Р 12.4.200-99 ССБТ. Одежда специальная для защиты от тепла и огня. Метод испытаний при ограниченном распространении пламени

1023. ГОСТ Р 12.4.205-99 ССБТ. Средства индивидуальной защиты от падения с высоты, удерживающие системы. Общие технические требования. Методы испытаний

1024. ГОСТ Р 12.4.207-99 ССБТ. Каски защитные. Общие технические требования. Методы испытаний

1025. ГОСТ Р 50862-96 Сейфы и хранилища ценностей. Требования и методы испытаний на устойчивость к взлому и огнестойкость

1026. ГОСТ Р 50941-96 (с изм. 1 1998) Кабина защитная. Общие технические требования и методы испытаний

1027. ГОСТ Р 51110-97 Средства защитные банковские. Общие технические требования

1028. ГОСТ Р 51111-97 Средства защитные банковские. Правила приемки и методы испытаний

1029. ГОСТ Р 51112-97 (с изм. 1 1998) Средства защитные банковские. Требования по пулестойкости и методы испытаний

1030. ГОСТ Р 51113-97 Средства защитные банковские. Требования по устойчивости к взлому и методы испытаний

1031. ГОСТ Р 51221-98 Средства защитные банковские. Термины и определения

1032. ГОСТ Р 51222-98 Средства защитные банковские. Жалюзи. Общие технические условия

1033. ГОСТ Р 51223-98 Средства защитные банковские. Шлюзы для передачи ценностей. Общие технические условия

1034. ГОСТ Р 51224-98 Средства защитные банковские. Двери и люки. Общие технические условия

1035. ГОСТ Р 1.0-92 (1997) Государственная система стандартизации Российской Федерации. Основные положения

1036. ГОСТ Р 1.2-92 (1997) Государственная система стандартизации Российской Федерации. Порядок разработки государственных стандартов

1037. ГОСТ Р 1.4-92 (1997)

1038. ГОСТ Р 6.30-97 (с изм. 12000$)$ Унифицированные системы документации.

Унифицированная система организационно-распорядительной документации. Требования к оформлению документов

1039. ГОСТ Р 50571.1-93 (ГОСТ 30331.1-95) Электроустановки зданий. Основные положения

1040. ГОСТ Р 50571.2-94 (МЭК 364-3-93) Электроустановки зданий. Часть 3. Основные характеристики

1041. ГОСТ Р 50571.3-94 (ГОСТ 30331.3-95) Электроустановки зданий. Часть 4. Требования по обеспечению безопасности. Защита от поражения электрическим током

1042. ГОСТ Р 50571.4-94 (ГОСТ 30331.4-95) Электроустановки зданий. Часть 4. Требования по обеспечению безопасности. Защита от тепловых воздействий

1043. ГОСТ Р 50571.5-94 (ГОСТ 30331.5-95) Электроустановки зданий. Часть 4. Требования по обеспечению безопасности. Защита от сверхтока

1044. ГОСТ Р 50571.6-94 (ГОСТ 30331.6-95) Электроустановки зданий. Часть 4. Требования по обеспечению безопасности. Защита от понижения напряжения

1045. ГОСТ Р 50571.7-94 (ГОСТ 30331.7-95) Электроустановки зданий. Часть 4. Требования по обеспечению безопасности. Отделение, отключение, управление 
1046. ГОСТ Р 50571.8-94 (ГОСТ 30331.8-95) Электроустановки зданий. Часть 4. Требования по обеспечению безопасности. Общие требования по применению мер защиты для обеспечения безопасности. Требования по применению мер защиты от поражения электрическим током

1047. ГОСТ Р 50571.9-94 (ГОСТ 30331.9-95) Электроустановки зданий. Часть 4. Требования по обеспечению безопасности. Применение мер защиты от сверхтоков

1048. ГОСТ Р 50571.10-96 (МЭК 364-5-54-80) Электроустановки зданий. Часть 5. Требования по обеспечению безопасности. Заземляющие устройства и защитные проводники

1049. ГОСТ Р 50571.11-96 (МЭК 364-7-701-84) Электроустановки зданий. Часть 7. Требования по обеспечению безопасности. Ванные и душевые помещения

1050. ГОСТ Р 50571.12-96 (МЭК 364-7-703-84) Электроустановки зданий. Часть 7. Требования по обеспечению безопасности. Помещения, содержащие нагреватели для саун

1051. ГОСТ Р 50571.13-96 (МЭК 364-7-706-84) Электроустановки зданий. Часть 7. Требования по обеспечению безопасности. Стесненные помещения с проводящим полом, стенами и потолком

1052. ГОСТ Р 50571.14-96 (МЭК 364-7-705-84) Электроустановки зданий. Часть 7. Требования к специальным установкам. Раздел 705. Электроустановки сельскохозяйственных и животноводческих помещений

1053. ГОСТ Р 50571.15-97 (МЭК 364-5-52-93) Электроустановки зданий. Часть 5. Выбор и монтаж оборудования. Глава 52. Электропроводки

1054. ГОСТ Р 50571.16-99 (МЭК 60364-6-61-86) Электроустановки зданий. Часть 6. Испытания. Глава 61. Приемо-сдаточные испытания

1055. ГОСТ Р 50669-94 (с попр. 1996) Электроснабжение и электробезопасность мобильных (инвентарных) зданий из металла или с металлическим каркасом для уличной торговли и бытового обслуживания населения. Технические требования

1056. ГОСТ Р 51628-2000 Щитки распределительные для жилых зданий. Общие технические условия

1057. ГОСТ Р МЭК 449-96 Электроустановки зданий. Диапазоны напряжения

1058. ГОСТ Р 51594-2000 Нетрадиционная энергетика. Солнечная энергетика. Термины и определения

1059. ГОСТ Р 51595-2000 Нетрадиционная энергетика. Солнечная энергетика. Коллекторы солнечные. Общие технические условия (взамен ГОСТ 28310-89)

1060. ГОСТ Р 51596-2000 Нетрадиционная энергетика. Солнечная энергетика. Коллекторы солнечные. Методы испытаний

1061. ГОСТ Р 51597-2000 Нетрадиционная энергетика. Модули солнечные фотоэлектрические. Типы и основные размеры

1062. ОСТ Р 51379-99 Энергосбережение. Энергетический паспорт промышленного потребителя топливно-энергетических ресурсов. Основные положения. Типовые формы

1063. ГОСТ Р 51380-99 Энергосбережение. Методы подтверждения соответствия показателей энергетической эффективности энергопотребляющей продукции их нормативным показателям

1064. ГОСТ Р 51387-99 Энергосбережение. Нормативно-методическое обеспечение. Основные положения

1065. ГОСТ Р 51388-99 Энергосбережение. Информирование потребителей об энергоэффективности изделий бытового и коммунального назначения. Общие требования

1066. ГОСТ Р 51541-99 Энергосбережение. Энергетическая эффективность. Состав показателей. Общие положения

\section{ЛИТЕРАТУРА}

1. Хохлова М. В. Обзор больших русскоязычных корпусов текстов //Труды объединённой научной конференции" Интернет и современное общество". - 2016. - С. 74-77.

2. Shavrina T., Shapovalova O. (2017) To the Methodology of Corpus Construction for Machine Learning: "Taiga" Syntax Tree Corpus and Parser. Корпусная лингвистика-2017, p.78 